Terr. Atmos. Ocean. Sci., Vol. 18, No. 2, 327-357, June 2007

\title{
Core Description and Characteristics of Fault Zones from Hole-A of the Taiwan Chelungpu-Fault Drilling Project
}

\author{
En-Chao Yeh ${ }^{1,5}{ }^{*}$, Hiroki Sone ${ }^{2}$, Taichi Nakaya ${ }^{3}$, Ka-Hao lan ${ }^{4}$, Sheng-Rong Song ${ }^{5}$, \\ Jih-Hao Hung ${ }^{4}$, Weiren Lin ${ }^{1}$, Tetsuro Hirono ${ }^{1}$, Chien-Ying Wang ${ }^{4}$, Kuo-Fong Ma ${ }^{4}$, \\ Wonn Soh ${ }^{1}$, and Masataka Kinoshita ${ }^{1}$
}

(Manuscript received 28 August 2006, in final form 24 January 2007)

\begin{abstract}
Taiwan Chelungpu-fault Drilling Project was conducted in drill site Dakeng, Taichung City of central western Taiwan during 2004 - 2005 principally to investigate the rupture mechanism in the northern segment of the Chi-Chi earthquake of 21 September 1999, and also to examine regional stratigraphy and tectonics. Core examination $(500-1800 \mathrm{~m})$ of Hole-A gave profound results aiding in illustrating the lithologic column, deformation structure, and architectural pattern of fault zones along the borehole.

Lithology column of Hole-A was identified downward as the Cholan Formation (500 - 1027 m), Chinshui Shale (1027 - 1268 m), Kueichulin Formation (1268 - $1712 \mathrm{~m}$ ), and back to the Cholan Formation (1712 - $2003 \mathrm{~m})$ again. A dramatic change is observed regarding sedimentation age and deformation structure around $1712 \mathrm{~m}$. Along the core, most bedding dips $30^{\circ}$ toward ${\mathrm{N} 105^{\circ}}^{\circ}$. Around $1785 \mathrm{~m}$, bedding dip jumps up to $70^{\circ}$ until the bottom of borehole. Five structure groups of different orientations (dip direction/dip) are observed throughout the core. Based on the orientation

\footnotetext{
${ }^{1}$ Kochi Institute for Core Sample Research, Japan Agency for Marine-Earth Science and Technology, Kochi, Japan

2 Department of Geology and Mineralogy, Kyoto University, Kyoto, Japan

${ }^{3}$ Department of Natural Environmental Science, Kochi University, Kochi, Japan

4 Department of Earth Sciences and Institute of Geophysics, National Central University, Chung-Li, Taiwan, ROC

${ }^{5}$ Department of Geosciences, National Taiwan University, Taipei, Taiwan, ROC

* Corresponding author address: Dr. En-Chao Yeh, Department of Geosciences, National Taiwan University, Taipei, Taiwan, ROC; E-mail: enchaoyeh@ntu.edu.tw doi: 10.3319/TAO.2007.18.2.327(TCDP)
} 
and sense of shear, they are categorized as thrust $(105 / 30)$, left-lateral fault $(015 / 30$ - 80), right-lateral fault $(195 / 30$ - 80), normal fault $(105 / 5-10)$, and backthrust (285/40 - 50). Ten fault zones have been recognized between 500 and $2003 \mathrm{~m}$. We interpret the fault zone located at around $1111 \mathrm{~m}$ as being the most likely candidate for rupture deformation during Chi-Chi earthquake. The fault zone seated around $\mathbf{1 7 1 2} \mathrm{m}$ is recognized as the Sanyi fault zone which is $600 \mathrm{~m}$ beneath the Chelungpu fault zone. Ten fault zones including thrust faults, strike-slip faults and backthrust are classified as the Chelungpu Fault System $(<\mathbf{1 2 5 0} \mathrm{m})$ and the Sanyi Fault System $(>1500 \mathrm{~m})$. According to the deformation textures within fault zones, the fault zones can be categorized as three types of deformation: distinct fracture deformation, clayey-gouge deformation, and soft-rock deformation. Fracture deformation is dominant within the Chelungpu Fault System and abother two architectures prevail in the Sanyi Fault System. The fracture deformation pattern is asymmetric, which depended the shear sense of fault zone. From the core examination of TCDP Hole-A, the lithology plays an important role in controlling the location and deformation of fault zones.

(Key words: Core description, Chi-Chi earthquake, Chelungpu fault, Sanyi fault, Deformation structure)

\section{INTRODUCTION}

A destructive earthquake $\left(\mathrm{M}_{\mathrm{w}}\right.$ 7.6) took place to the east of Nantou city of central Taiwan on 21 September 1999 . The hypocenter was determined at $120.81^{\circ} \mathrm{E}, 23.86^{\circ} \mathrm{N}$ and a depth of $10 \mathrm{~km}$ (Kao et al. 2000), which was close to the town Chi-Chi. Besides bending in the northern segment, the surface rupture during the Chi-Chi earthquake is generally along the north-south trending Chelungpu fault zone at about $85 \mathrm{~km}$ in length with complicated surface deformation (Ma et al. 1999; Lee et al. 2002; Angelier et al. 2003). Faulting during the Chi-Chi earthquake was thrust movement with minor left-lateral shear on a N-S trending fault plane with a dip of $30^{\circ}$ to the east (e.g., Heermance et al. 2003).

The seismic behavior and surface deformation of the Chi-Chi earthquake is dramatically different between the north and south segments (e.g., Ma et al. 1999; Ma et al. 2000). In the north, the seismic slip is characterized by large slip (maximum $>10 \mathrm{~m}$ ), fast slip velocity and low frequency acceleration. In contrast, the ground motion is illustrated by small displacement ( $3-4 \mathrm{~m}$ ), low slip velocity, but high frequency acceleration in the south segment. The mechanism to create the different characteristics of seismic motion between the north and south segments is still unclear.

The continuous coring provides us a great opportunity to observe and analyze a complete profile of fault zone structures in order to understand the earthquake mechanism. The coring from two previous shallow drilling holes penetrating the slip zone of the Chi-Chi earthquake has been conducted by JSTA (Japan Science and technology Agency) in April 2000. The total length of retrieved core is $540.80 \mathrm{~m}(0-293 \mathrm{~m}$ and $207.50-455.30 \mathrm{~m}$ for the main well and 
side- track, respectively) in the northern well of the Fengyuan city and $211.20 \mathrm{~m}$ in the southern well of the Nantou City. Two fault zones of the potential Chi-Chi earthquake slip are observed in each drill site (Tanaka et al. 2002). However, in the shallow drilling holes, the exact fault zone corresponding to the Chi-Chi earthquake slip is not confirmed yet, nor is the rupture mechanism is fully understood. In addition, the relation between the Chelungpu fault zone, the underneath Sanyi fault zone, and the extension of the Sanyi fault zone into central Taiwan are not yet fully comprehended. In order to better understand seismogenic behavior of the Chi-Chi earthquake and the characteristics of the Chelungpu and Sanyi fault zone, the Taiwan Chelungpu-fault Drilling Project (TCDP) has been proposed by National Central University (NCU) and National Taiwan University (NTU) and supported by International Continental Drilling Project (ICDP) and Japan Agency for Marine-Earth Science and Technology (JAMSTEC). The plan for Hole-A of the TCDP is to drill $2000 \mathrm{~m}$ with coring to take place continuously from 500 to $2000 \mathrm{~m}$, to deploy different downhole logging, and, after coring, to install long-term monitoring instruments. The $2000 \mathrm{~m}$ drilling was finished successfully in December 2004. Furthermore, coring at Hole-B, 39 m southeast of Hole-A, was completed from 950 to $1350 \mathrm{~m}$ in early of May 2005.

This paper reports the core description from Hole-A of the TCDP. We summarize the variation of lithology, bedding dip, structure orientation, fracture density and vein distribution for depths between 500 and $1800 \mathrm{~m}$ and the location of fault zones. Also, architectural characteristics of observed fault zones are documented in detail. Furthermore, we discuss potential fault rupture during the Chi-Chi earthquake, the location of the Sanyi fault zone and the role of lithology in developing the fault zones.

\section{TECTONIC SETTING AND GEOLOGICAL BACKGROUND OF THE CHI-CHI EARTHQUAKE}

The Taiwan mountain belt marks an oblique convergent boundary between the Eurasian and Philippine Sea Plates (Fig. 1a; insert; e.g., Biq 1972; Chai 1972; Bowin et al. 1978; Barrier and Angelier 1986; Ho 1986; Teng 1990; Lu and Hsu 1992; Liu et al. 1997; Wu et al. 1997). The South China Sea of the Eurasian Plate is moving eastward and subducting beneath the Philippine Sea Plate in the south, producing the Luzon Arc. At the same time, the Luzon Arc seated on the Philippine Sea Plate is moving toward $306^{\circ}$ at a speed of $81 \mathrm{~mm} \mathrm{yr}^{-1}$ (Yu et al. 1997) and is colliding with the Eurasian continental margin, resulting in Taiwan island. Also, the Philippine Sea Plate is subducting beneath the Eurasian continental margin in the northeast of Taiwan, creating the Ryukyu Trench and the Okinawa Trough. This ongoing oblique collision and intersection between two subduction systems results in active faulting, numerous earthquakes and crustal deformation within the Taiwan mountain belt.

From west to east, the Taiwan mountain belt can be subdivided physiographically into the Coastal Plain, the Western Foothills, the Hsüehshan Range, the Central Range, the Longitudinal Valley and the Coastal Range (Ho 1988). Among these physiographic domains, one of the most active regions within Taiwan island is along the boundary between the Coastal Plain and the Western Foothills. Several disastrous earthquakes have been observed along this boundary, including the 1999 Chi-Chi earthquake (Wang et al. 2000). The related stratigraphic formation around this active region are Pleistocene Toukashan Formation (1 - $2 \mathrm{~km}$ thick conglomerate 


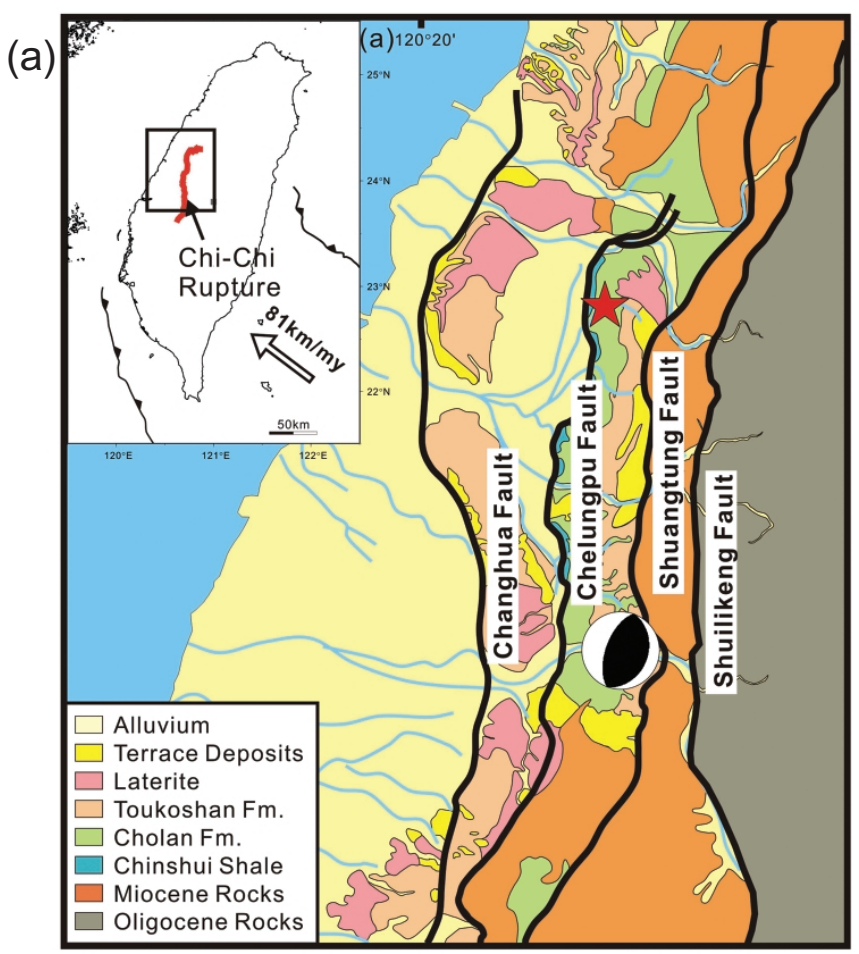

(b)

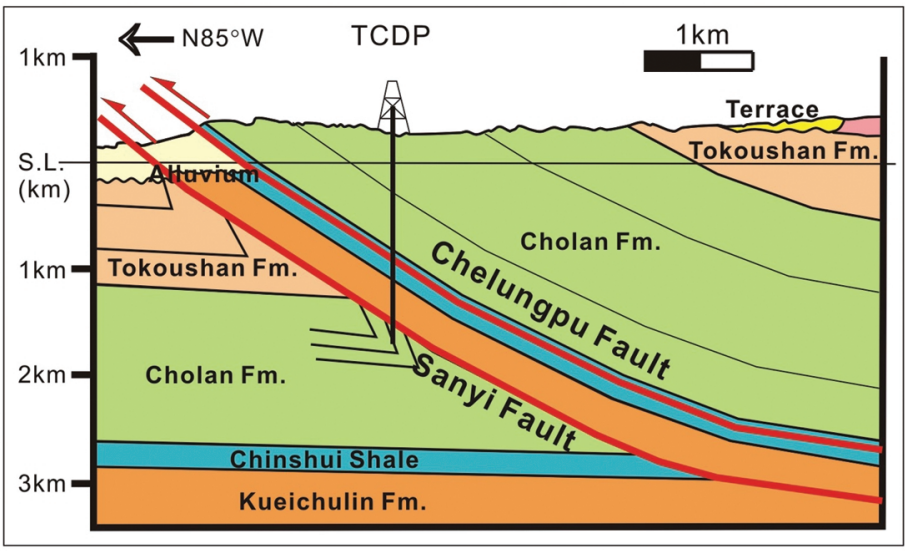

Fig. 1. Geological map of western Taiwan and cross-section near the drill site. (a) Geological map displays the formation distribution and the major fault zones in the central portion of the western Taiwan (after Wang et al. 2002). The TCDP site is indicated by a red star. The focal mechanism of the Chi-Chi main shock is located at the hypocenter of the Chi-Chi earthquake (Kao and Chen 2000). The insert is the tectonic setting of Taiwan. (b) Cross section through the drill site illustrates the relation between formations and major fault zones (after Hung et al. 2007). 
and alternations of fluvial-shallow marine sandstone and siltstone), early Pleistocene-Pliocene Cholan Formation (1.5 - $2.5 \mathrm{~km}$ thick monotonous alternating sandstone and siltstone), early Pliocene Chinshui Shale ( $300 \mathrm{~m}$ thick shale and siltstone), late Miocene-early Pliocene Kueichulin Formation (0.8 - $2 \mathrm{~km}$ thick shallow marine sandstone and shale) and middle Miocene Nanchuang Formation (800 - 900 m thick core-bearing sandstone, siltstone and shale) (Fig. 1a; Ho 1988). However, the formation was crosscut and over stacked by three major faults around this active seismic belt. From west to east, these faults are the Changhua, Chelungpu, and Shuangtung faults (Fig. 1a). They are forming the west-verging imbrication structure of a fold-and-thrust belt (Suppe 1981; Davis et al. 1983). Among these faults, the Chelungpu fault zone plays the major role in the Chi-Chi earthquake.

The Chelungpu fault zone is one of the major faults in western Taiwan. This fault is a west-verging thrust fault of over an $80 \mathrm{~km}$ in length and separates the low level plain and basin regions from the high altitude areas of hills and mountains. Because of its distinct geomorphic feature, this fault is considered an active fault (Bonilla 1977). The Chelungpu fault zone originally was described as the Chinshui Shale overthrusting the Toukashan Formation in the southern Taichung Basin (Chang 1971). During the Chi-Chi earthquake, the surface rupture closely followed the Chelungpu fault zone. In contrast, two other major fault zones next to the Chelungpu fault zone (i.e., Changhua fault zone in the west and Shuangtung fault zone in the east) did not slip significantly (Yu et al. 2001; Hung et al. 2002; Pahier et al. 2003). Because of no distinctive slip in the deformation front (i.e., the Changhua fault zone) during the Chi-Chi earthquake, it is reasonable to say that the Chi-Chi earthquake faulting is an out-of-sequence event. Result of focal mechanism and focal depth determined by seismologic inversion and relocation also indicates the characteristics of an out-of-sequence event (Kao and Chen 2000). Regionally, the surface displacement during the Chi-Chi earthquake is approximately parallel to the direction of tectonic convergence (Yang et al. 2000). On the surface survey, the hanging wall of the Chi-Chi earthquake rupture is composed of alternating beds of sandstone and siltstone of Pliocene Cholan Formation and the early Pliocene Chinshui Shale. The footwall is composed of Pleistocene Toukashan Formation and recent alluvial deposits. Thus, the relationship of hanging wall and footwall between the Chi-Chi earthquake and the Chelungpu fault zone is consistent. Also, the earthquake surface rupture dips $30^{\circ}$ toward the east, similar to the dip of the Chelungpu fault zone. Most slip of the Chi-Chi earthquake is found within and nearly parallel to the bedding plane of Chinshui Shale (Lee et al. 2001). However, the spatial relationship between the Chi-Chi earthquake faulting and the pre-existing Chelungpu fault zone at depth is still unclear. Whether both converged into one slip plane or they ruptured in different slip planes is not well understood.

The Sanyi fault zone is also a thrust fault verging to the west. Meng (1963) argued that the Sanyi fault zone was the northern extension of the Chelungpu fault zone. However, it is only clearly defined between the north margin of Taichung basin and the Sanyi area. Furthermore, based on surface mapping, the Sanyi fault zone was observed as the lower member of middle Miocene Nanchuang Formation or late Miocene-early Pliocene Kueichulin Formation overthrusting Pleistocene Toukashan Formation (Chang 1971). As a consequence, the Sanyi fault zone might be located in a different structural level from the Chelungpu fault zone (Fig. 1b). The location of the Sanyi fault zone in the Taichung area and its relationship with the Chelungpu fault zone can be evaluated by the $2000 \mathrm{~m}$-depth coring of the TCDP. 


\section{DRILLING OVERVIEW}

The drill site of the TCDP is located on Dakeng, Taichung County, $2 \mathrm{~km}$ east of the surface rupture of the Chi-Chi faulting (Fig. 1a). The elevation of the drill site $\left(120.73916^{\circ} \mathrm{E}\right.$, $24.20083^{\circ} \mathrm{N}$ ) is about $247 \mathrm{~m}$. Subsurface structures around the drill site were constructed by high-resolution shallow reflection seismic profiles (Wang et al. 2002, 2004). The mapping suggested that: (1) the Chi-Chi rupture is at a depth of $1200 \mathrm{~m}$ beneath the drill site; and (2) the Sanyi fault zone might be seated beneath the $\sim 800$ thick Kueichulin Formation and beneath the Sanyi fault zone; it might be the Toukashan conglomerate formation. Additionally, the constraint of spatial slip distribution from strong motion stations (Ma et al. 2001) and geodetic data (Yang et al. 2000; Yu et al. 2001; Lee et al. 2003) shows a coseismic slip of $12 \mathrm{~m}$ around the drill site.

TCDP carried out continuous coring from 500 - 2003 m down for Hole-A. We use a PQ-S sized core barrel ( $3 \mathrm{~m}$ long and $83 \mathrm{~mm}$ in diameter) with the wire-line method. This coring merges an oil-rig drilling system and a wireline coring system, leading to a different operation from the traditional PQ and HQ wireline coring methods. We used a coring bit of a diameter of 6.22 " for $500-1300 \mathrm{~m}$ and 6" for $1300-2003 \mathrm{~m}$. For Hole-A of the TCDP, above $661 \mathrm{~m}$, the drilling-coring operation progressed slowly due to difficult geological conditions and mechanical problems (Fig. 2). For example, we encountered conglomerate at around a drilling depth of $43-48 \mathrm{~m}$ and underground water at a depth of around $140-150$ and $390 \mathrm{~m}$. Especially, at the interval $140-150 \mathrm{~m}$, drillers had to refill the borehole with cement and re-drill several times. However, after the first casing and cementing at $661 \mathrm{~m}$, coring was smooth, except for a long stop at $1301 \mathrm{~m}$ due to the standby time of logging, secondary casing, cementing, and changing the engine. Well logs were carried out for $500-1870 \mathrm{~m}$ with 3 sections in order to evaluate the physical properties of fault rock and wall rock.

The orientation, including deviation and azimuth, of Hole-A and core recovery are summarized herein (Fig. 3). The main portion of Hole-A, expectedly, was drilled vertically. The borehole trajectory shows that the deviation of the borehole was mainly retained within $3^{\circ}$ above $1600 \mathrm{~m}$, but became larger after $1600 \mathrm{~m}$ and reached to $14^{\circ}$ at $1860 \mathrm{~m}$ (Fig. 3a). It turned out that the borehole became highly unstable between 1800 and $1900 \mathrm{~m}$. In fact, no logging tool could be deployed deeper than $1870 \mathrm{~m}$. The azimuth of a borehole is typically opposite the dip direction of bedding. The azimuth of the borehole was around N275 - $290^{\circ}$ above $1110 \mathrm{~m}$ (Fig. 3b), which was consistent with the prediction, provided the dip direction $\mathrm{N} 105^{\circ}$ of regional bedding. However, after passing the interval of the first two fault zones $(1106-1157 \mathrm{~m})$, the azimuth changed into $250-260^{\circ}$ and maintained this range until $1500 \mathrm{~m}$. Furthermore, after a fault zone at around $1525 \mathrm{~m}$ down, the azimuth jumped to $190^{\circ}$ and varied between $150^{\circ}$ and $200^{\circ}$ until $1860 \mathrm{~m}$.

The influence of borehole trajectory on the coring can be evaluated according to core recovery (Fig. 3c). Because the core usually is not broken at the bottom of the drill bit, the curated length of retrieved core is different from the drilling length most of the time. Moreover, the retrieved core might include previous coring(s), i.e., core recovery could be over $100 \%$ in some runs. As we can see in Fig. 3c, the pattern of difference between curated length and drilling length for each retrieval shows that the difference: (1) increased at $500-661 \mathrm{~m}$; (2) kept less than $1 \mathrm{~m}$ at $661-1200 \mathrm{~m}$; (3) slightly increased at $1200-1523 \mathrm{~m}$; (4) significantly 
changed at $1523-1600 \mathrm{~m}$; (5) dramatically increased at 1600 - $1900 \mathrm{~m}$; and (6) finally maintained less than $1 \mathrm{~m}$ at $1900-2003 \mathrm{~m}$. These observations suggest that variation in core recovery might be due to the change in borehole azimuth (transition zones of T1 and T2), fluctuation in borehole azimuth (fluctuation zones of F1 and F2), and the variation of the borehole deviation (F2). Thick fault zones with soft material might be the main reason for the variation of borehole orientation, further influencing the variation of core recovery. However, overall recovery is still pretty good $(\sim 97 \%)$ and most of the core is continuous. Also, no distinct disturbance induced by borehole deviation on the core at the fault zones is observed.

\section{CORE DESCRIPTION}

The depth of the core and the orientation of structure in the core are essential elements. Therefore, we first define the basic referencing for core depth and structure orientation before reporting the results of the visual core description. For presenting our results, we will first demonstrate lithology and bedding dips with respect to depth. Then, general deformation structures between 500 - $1800 \mathrm{~m}$ down will be presented. Based on structure data, fracture density with depth will be shown and correlated to the location of fault zones. Also, distribution of mineralization is reported. Finally, we will describe the characteristics of ten fault zones identified from the retrieved core of Hole-A and summarize the general features of fault zones.

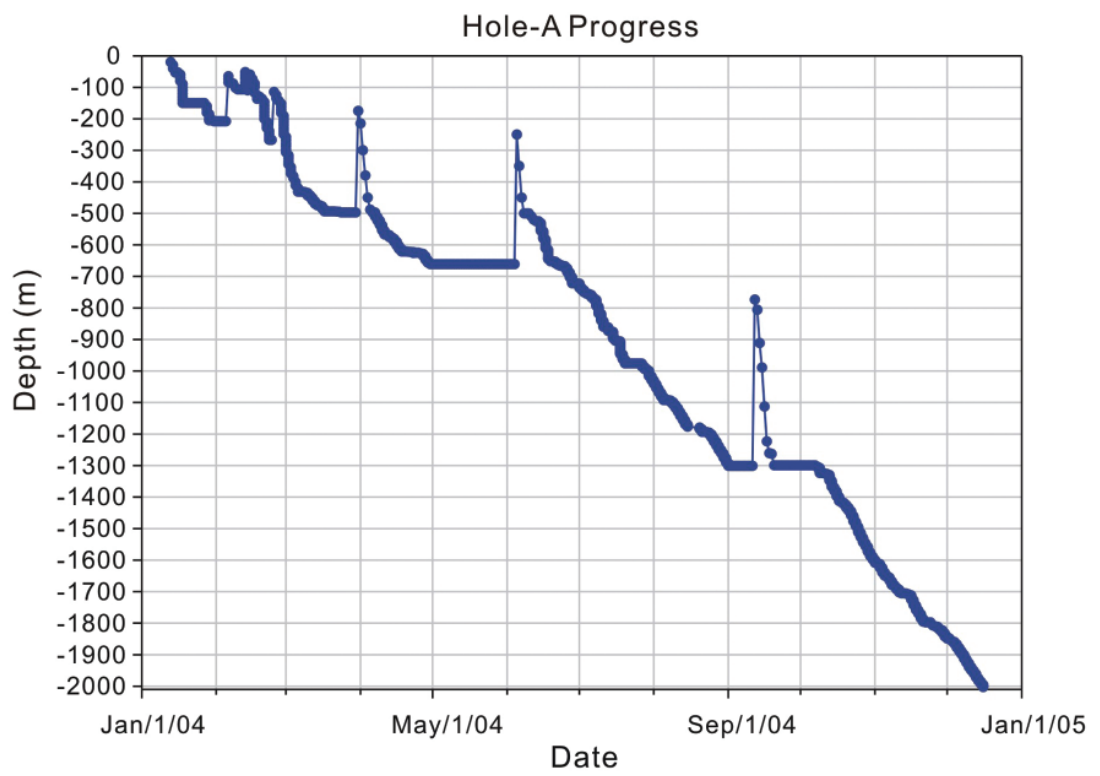

Fig. 2. Progress of Hole-A TCDP. Several long delays in the depths of 43 - 48, $140-150,390,661$, and $1310 \mathrm{~m}$ were encountered by difficult geologic conditions, mechanical problems and standby time of logging. 


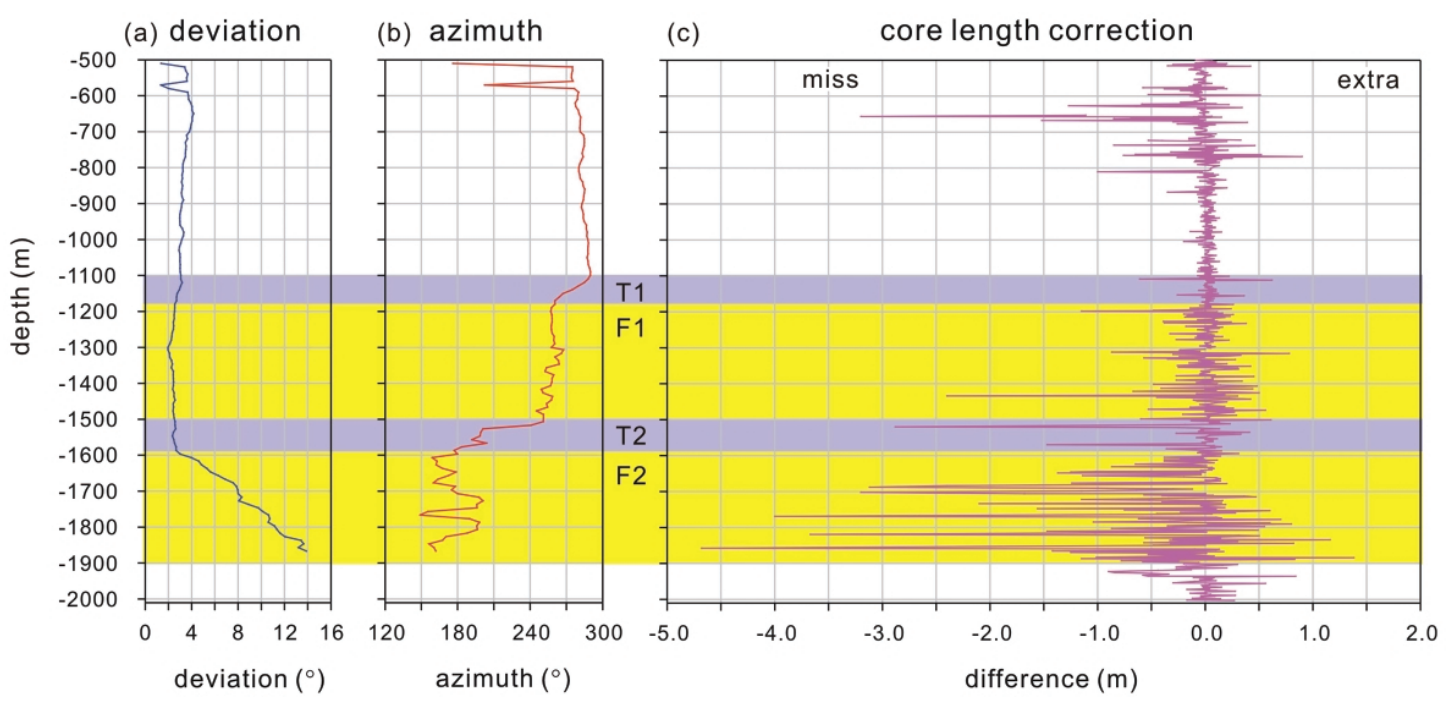

Fig. 3. Correlation between borehole trajectory and core recovery. (a) Plot of deviation with depth. Deviation keeps less than $3^{\circ}$ till $1600 \mathrm{~m}$ but reaches $\sim 14^{\circ}$ at $1860 \mathrm{~m}$. (b) Plot of azimuth with depth. Azimuth keeps constant above $1100 \mathrm{~m}$ but decreases after the transition zones (T1 and T2) and flacuates within the flacuatation zones (F1 and F2). (c) Plot of core length correction with depth. Core recovery is strongly affected by borehole trajectory. Recovery is stable within the transition zones but is pretty bad within the flacuation zones.

\subsection{Basic Referencing for the Depth and Orientation}

Depth referencing for coring was setup at a rotary table, $3 \mathrm{~m}$ above the ground's surface. All recorded depths of retrieved core are uncorrected drilling depths below the rotary table, not the wireline-log depth. Taking into account the uncorrected error in drilling depth of the retrieved core by accumulating the individual length-differences between core- and drillinglength for the data shown in the Fig. 3c, the loss of core length will be less than $8 \mathrm{~m}$ for the interval $500-661 \mathrm{~m}(5 \%), 12 \mathrm{~m}$ for $661-1301 \mathrm{~m}(2 \%), 12 \mathrm{~m}$ for $1301-1649 \mathrm{~m}(3 \%)$, and $50 \mathrm{~m}$ for 1649 - $2003 \mathrm{~m}(14 \%)$. The most significant error accumulation takes place after $1649 \mathrm{~m}$. The accumulated error in driller's depth should be smaller than $3 \mathrm{~m}$ due to the coring barrel being $3 \mathrm{~m}$. Because of few clear marks on the core for resetting the core- and drilling-length at the same run, we are not able to make the core depth more accurate at this stage. As a result, although we cannot correct the core depth, our presented data $(500-1800 \mathrm{~m})$ should be still acceptable (error $<3 \mathrm{~m}$ ). 
The structure orientation presented here is geographic coordination. For the coordination system in the core, we use a regional bedding dip direction of $\mathrm{N} 105^{\circ}$ determined by field measurement as the reference direction, assuming that the bedding orientation in the drill hole is consistent with that of the regional bedding and its orientation does not change significantly from top to bottom in general. The assumption is reasonable, based on the overall bedding dip

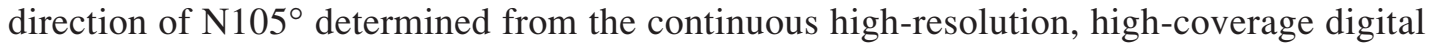
borehole electrical resistivity images in Hole-A (Hung et al. 2007). We marked the reference lines on the core right after the core was cleaned with a wet sponge. In detail, a blue line was drawn to align with the down-dip direction of the bedding dip. A red line was drawn parallel to the blue line and was referenced to identify the top-bottom direction of core by its relative position to the blue line. Dip of bedding and deformation structure was measured with respect to the core axis and, then, was corrected to the conventional dip representation. Dip direction of the features was measured relative to the blue reference line. However, we did not correct the effect of the borehole trajectory since we do not have detailed core-log correlation. Also, as described earlier, severe distortion of the borehole happened only after a depth of $1600 \mathrm{~m}$. Although the measurement error $\left( \pm 5^{\circ}\right)$ on the core and the error $\left( \pm 10^{\circ}\right)$ from the borehole trajectory for the structure orientation we presented here are not highly accurate, they are acceptable.

\subsection{Litholgy Column and Bedding Dip}

Core description was recorded with traditional description items of sedimentary rock and deformation structures by visual examination. Here, the lithologic column is exhibited (Fig. 4a). Lithology was classified into five categories based on grain size and intensity of bioturbation. For lithology classification, " 1 " notes pure siltstone/shale, " 2 " is a combination of major portion siltstone with minor portion sandstone, " 3 " indicates major-portion sandstone and minorportion siltstone, " 4 " shows intensive bioturbated rock, and " 5 " is pure sandstone. By using this lithologic classification, we define four lithologic units in Hole-A (Fig. 4a), which is consistent with geological formations. Unit A, B, C, and D are correlated to the Cholan Formation, Chinshui Shale, Kueichulin Formation and Cholan Formation, respectively. In detail, Unit A (500 - $1027 \mathrm{~m}$ ) is made up of alternating layers of sandstone and siltstone. Unit B (1027 - $1268 \mathrm{~m})$ consists of mainly siltstone with some thick sandy layers (10 - $20 \mathrm{~m}$ width). Unit C (1268 - $1712 \mathrm{~m})$ is composed of sandstone interbeded with siltstone. Unit D (1712 $2003 \mathrm{~m}$ ) is a monotonous alternation of sandstone and siltstone, which is very similar to Unit A. Based on the lithostratigraphic characteristics of the top of Chinshui Shale (Ho 1986; the first appearance of thick black shale right below the thick sandstone with intensive bioturbation), the boundary between the Cholan Formation (Unit A) and Chinshui Shale (Unit B) is determined at $1027 \mathrm{~m}$. Furthermore, the boundary between the Chinshui Shale and Kueichulin Formation (Unit C, i.e., the thick sandstone below finer thick siltstone) is around $1268 \mathrm{~m}$. The observation of one major fault at $1712 \mathrm{~m}$ with a distinct oyster layer of Cholan Formation around $1754 \mathrm{~m}$ suggests that fault contact (Sanyi fault zone) existed between Kueichulin Formation and Cholan Formation (Unit D) at $1712 \mathrm{~m}$.

Bedding dip is constant for most places except some disturbed fault zones. Mostly bedding dip is about $30^{\circ}$ measured from the core, but the dip changed dramatically into $60-70^{\circ}$ right below $1785 \mathrm{~m}$ (Fig. 4b). However, the dip changed back to $30^{\circ}$ right after passing a fault 


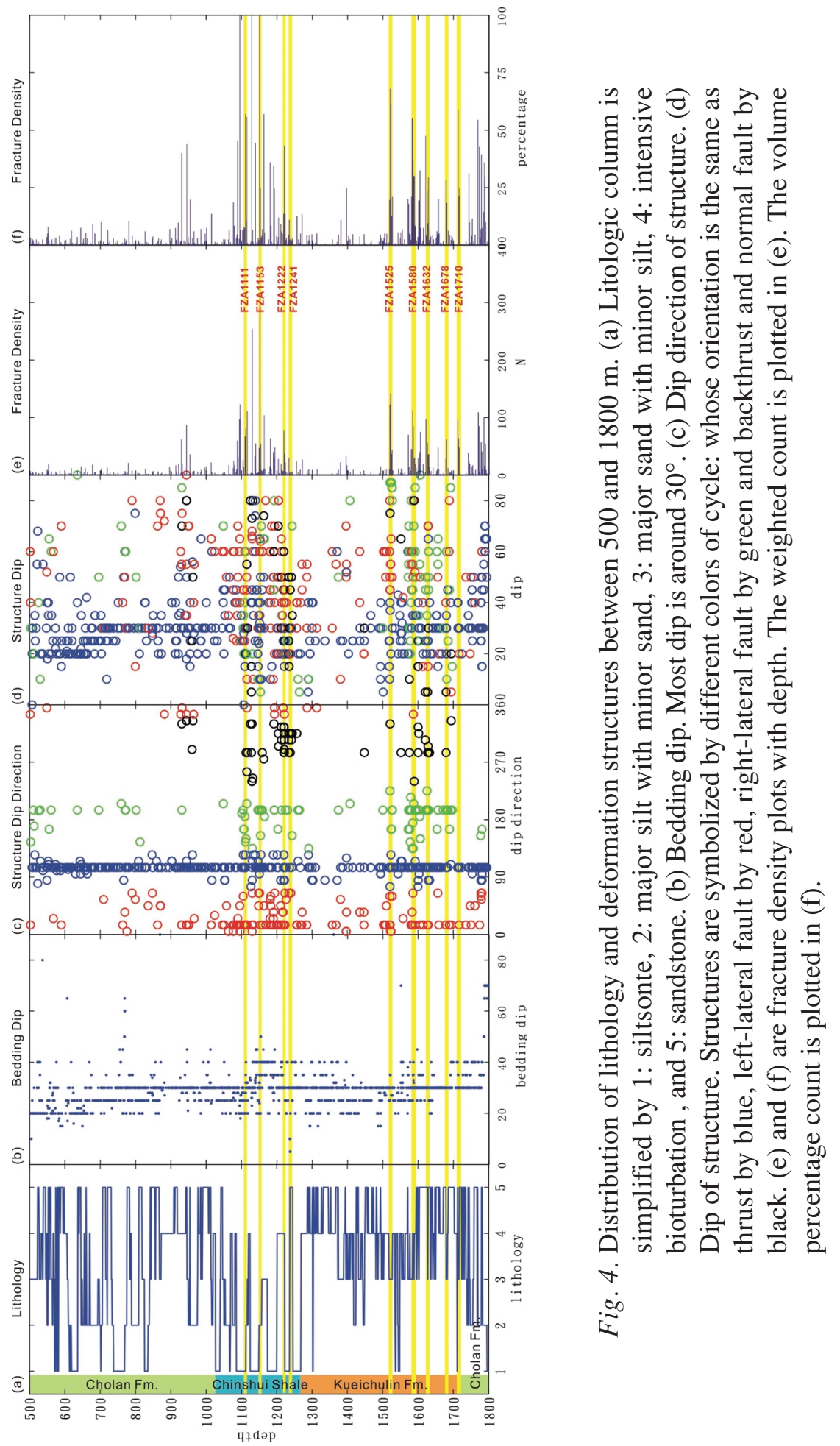


zone at $1856 \mathrm{~m}$. For the fault zone of Hole-A at $1111 \mathrm{~m}$ down (FZA1111), there is a trend in bedding dip change from $30^{\circ}$ to $20^{\circ}$ and bedding dip changes back to $30^{\circ}$ right after passing FZA1111. Other minor variations in bedding dip disturbed by fault zones are reported by Hung et al. (2007).

\subsection{DEFORMATION STRUCTURE}

\subsubsection{General Description}

Five groups of structures with different orientation can be identified from core examination. They are composed of vein, fracture, breccia and gouge. Some structures have observable kinematic indicators, leading them to be classified as micro-faults. The kinematics indicators we used include alternating-polished-and-rough-facets, calcite-steps, and key bed displacement (cf. Angelier 1994). The calcite-steps commonly exist on fault planes shallower than a depth of $1300 \mathrm{~m}$. Besides low-angle normal micro-faults with clear calcite-steps, other types of micro-faults contain both calcite-steps and alternating-polished-and-rough-facets as shearsense indicators. Micro-faults with certain shear sense usually belong to a distinctive orientation group. Based on the geometry (dip direction/dip) and sense of shear, they are recognized as thrust $(105 / 20$ - 60), left-lateral fault $(015 / 30$ - 80), right-lateral fault (195/30 - 80), backthrust (285/30) and normal fault (105/5 - 10). Because not all structures have kinematic indicators, our plot of structure category (Figs. 4c, d) thus only shows basic groupings of structure (width $>1 \mathrm{~cm}$ ) of similar orientation, even though we plot them as micro-faults. Also, the plot doesn't mean that all the structures in the same group have the same shear sense, i.e., structures in the same group were not necessarily developed by the same kinematics. However, the distribution of structural groups along the borehole is strikingly distinctive. For thrust, the dip direction of thrust is parallel to the down-dip direction of bedding. Some are bedding parallel slip and others cut the bedding with a high angle. From core observations, the high-angle thrust usually crosscuts the bedding-slip thrust. For the strike-slip fault, left-lateral and right-lateral faults alternatively developed along the core. We expected them to be conjugated faults in regional scale. However, the left lateral fault is more dominant. Backthrust, which is believed to be associated with thrust kinematics, is observed around $950 \mathrm{~m}$ and within some major fault zones. The normal microfault is mainly observed within the depth of $1262-1283 \mathrm{~m}$.

The orientation and population of structures groups are shown in the rose diagram (Figs. 5a, b). In order to evaluate the effect of width, both rose diagrams of structures with width larger and smaller than $1 \mathrm{~cm}$ are plotted. From the orientation statistics, both patterns are similar, suggesting our measurement is not biased, even with structure width less than $1 \mathrm{~cm}$. Also, the population of structures with the same orientation of thrust is highest. Structures with strikeslip fault orientation are the next highest ones. The next one is backthrust. Normal faulting is the least apparent. Compared with the inferred stress distribution of the dipole sonic image result (Hung et al. 2007), the kinematics of structure and its distribution are compatible with the expected kinematics and distribution of derived maximum horizontal stress direction.

Fracture density can provide insight into understanding structure distribution along the depth. Here, fracture densities with two different counting methods are displayed (Figs. 4e, f). 
(a)

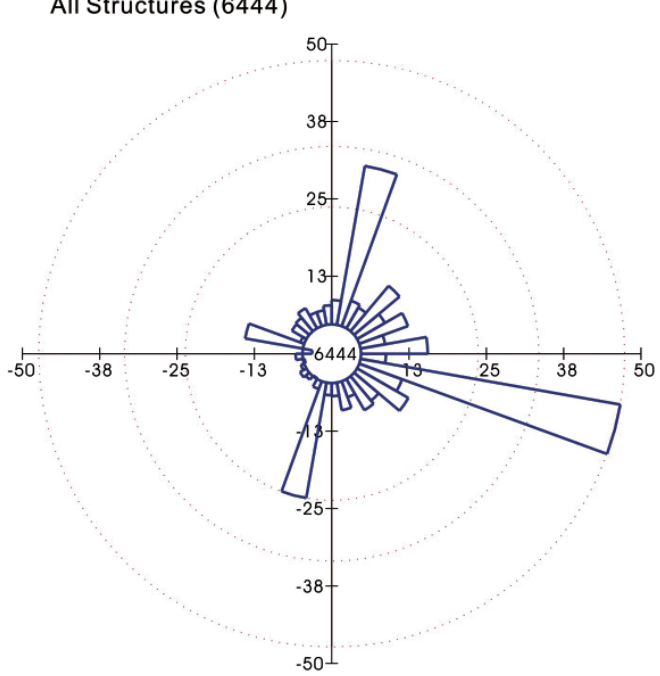

(b)

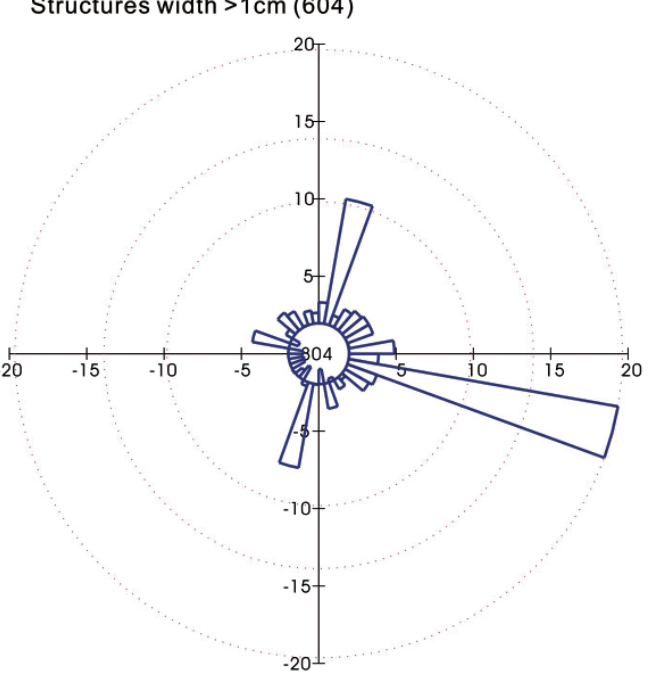

Fig. 5. Rose diagram of structure azimuth between 500 and 1800 m. (a) All 6444 structures. (b) 804 structures with width larger than $1 \mathrm{~cm}$.

We count structures with width larger than $1 \mathrm{~cm}$ by using the multiple-count as $1 \mathrm{~cm}$ for 1 count within a bin of $2 \mathrm{~m}$ and the percentage-count of total structure width within a bin of $2 \mathrm{~m}$. The fracture densities from these two methods are different but the results are very similar. Basically, the fracture density pattern is consistent with the distribution of the major fault zones. For more details, the observations on both plots (Figs. 4e, f) indicates: (1) sporadic structures from 500 to $900 \mathrm{~m}$; (2) one intensive deformation zone around $900-1000 \mathrm{~m}$, especially around $925 \mathrm{~m}$; (3) increasing fracture density downward from $1050 \mathrm{~m}$; (4) a thick deformation zone between 1100 and $1250 \mathrm{~m}$; (5) a structure quiescent zone between 1300 and $1500 \mathrm{~m}$, except around $1400 \mathrm{~m}$; (6) one thick deformation zone between 1500 and $1712 \mathrm{~m}$; and (7) another intensive deformation zone around $1750-1800 \mathrm{~m}$. Two intensive deformation zones of 1100 - $1250 \mathrm{~m}$ and 1500 - $1712 \mathrm{~m}$ actually correspond to the Chelungpu Fault System and the Sanyi Fault System, respectively (see the below).

\subsubsection{Mineralization}

Mineralization can be an indicator of the fluid conduit and also can provide information about the deformation stage. Mineral filling is very common on the Hole-A core of the TCDP, but is usually very thin $(<2 \mathrm{~mm})$. Most mineral filling is carbonate composition shallower than $1618 \mathrm{~m}$; however, some thin filling, below $1618 \mathrm{~m}$, is no-stiff white minerals (quartz?) with no reaction to $\mathrm{HCl}$ acid. Certainly, there is an increasing trend for filling mineral development with depth (Fig. 6). The distribution of calcite veins is a multiple-clustering pattern and gradu- 
ally increases to a maximum around $1250 \mathrm{~m}$ and ends suddenly around $1300 \mathrm{~m}$. Below $1300 \mathrm{~m}$, it is a quiescent zone as revealed by fracture density patterns until $1500 \mathrm{~m}$, except at around $1450 \mathrm{~m}$. Another gradual growing mineral-filling starts from $1500 \mathrm{~m}$ and reaches a maximum at around $1620 \mathrm{~m}$. After that, the main composition of filling-mineral changes and mineralfilling density decreases until $1730 \mathrm{~m}$. The mineral filling pattern suggests that there might be two separate major fluid conduits, one at around $1285 \mathrm{~m}$ and the other $1620 \mathrm{~m}$. The fluid conduit of $1285 \mathrm{~m}$ down might be correlated with the above mentioned unusual low-angle normal faults of $1263-1285 \mathrm{~m}$.

Mineral filling exists not only as vein but also as calcite steps within micro-faults. If a higher abundance of calcite-filling on a microfault corresponds to a longer activation of the microfault, then we should be able to determine the relative age of different groups of microfaults based on their calcite-filling abundance. From our observation, most intensive calcitefilling is found on the left-lateral fault when all micro-faults coexisted in the same core. Thus, the left-lateral fault could be the older deformation structure. However, left-lateral fault, thrust, and right-lateral faulting cross-cut each other in some cases. So, we interpret that the leftlateral fault is the older deformation but left-lateral fault, thrust, and right-lateral faulting de-

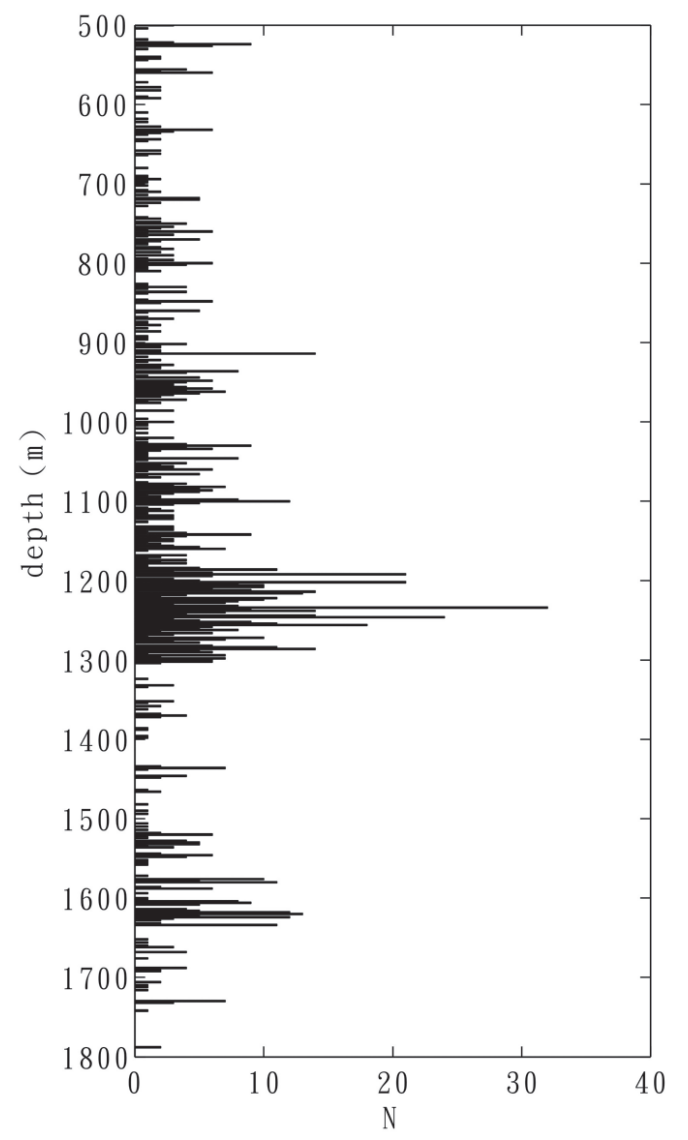

Fig. 6. Histogram of mineralization distribution by a single count with the bin of $2 \mathrm{~m}$. A multiple-clustering pattern exists above $1300 \mathrm{~m}$ and vein number increases to a maximun at $1250 \mathrm{~m}$ and suddenly ends around $1300 \mathrm{~m}$. Another growing number of filling veins exists between 1500 and $1712 \mathrm{~m}$. 
veloped in the same period. But, no clear deformation stage can be recognized for backthrust and normal faulting.

\subsubsection{Fault Zones}

Based on fracture density and fault architecture, ten major fault zones between 500 and $2003 \mathrm{~m}$ of TCDP Hole-A are identified. They are named as the Fault Zone of Hole-A at $1111 \mathrm{~m}$ down (FZA1111), FZA1153, FZA1221, FZA1241, FZA1525, FZA1581, FZA1632, FZA1679, FZA1712, and FZA1856 (Figs. 7 - 16). There might be more major fault zones around 1800 $1850 \mathrm{~m}$; however, without more detailed destructive examination by splitting cores and making thin sections, we are not able to determine whether they are natural or artificial by the coring process. For those ten fault zones, the shallower four fault zones, including the Chelungpu fault zone (one of FZA1111, FZA1153, and FZA1221), are within the siltstone-dominant region and the deeper six fault zones, including the Sanyi fault zone (FZA1712), are within the sandstone-dominant region. Therefore, we called the shallower four fault zones and the deeper six fault zones as the Chelungpu Fault System and the Sanyi Fault System, respectively. Both of them are also strongly correlated to the fluid conduits inferred from the mineralization distribution (Fig. 6). More interestingly, the fault spacing for the Chelungpu Fault System is roughly about 40 - $50 \mathrm{~m}$, except FZA1244; and also approximately 40 - $50 \mathrm{~m}$ for the Sanyi Fault System, except FZA1856. This consistent regional fault-spacing in these two Fault Systems might reflect some fundamentally intrinsic characteristics about material properties in the context of the fracture mechanics.

Here we define the terminology used for fault texture and architecture before describing the fault zones. The terminology for the damage zone and fault core is adopted from that defined by Chester et al. (1993) (Table 1). For texture description, we use the terms including fracture, breccia, gouge and ultra-cataclasite defined by Sibson (1977). In Table 1, the damage zone is the same as the fracture zone and the fault core includes breccia and gouge zones. We will use the word "width" to represent the core length of a certain structure/layer.

In the context of fault architecture, the components of deformation zones of fracture, breccia, gouge and ultra-cataclasite are identified within a fault zone. Based on different combinations and different distributions from fracture, breccia, gouge zones and ultra-cataclasite, the different fault architecture is constructed. For example, in our description of fault zones, fracture deformation means that each deformation component has a certain comparative volume in the fault zone. i.e., each zone is comprehensible and distinct. Some of these zones exhibit increasing deformation upwards or downwards, depending on the fault types. What we call "soft-rock deformation" is sandy-rock on recovered cores that is soft and deformable to the touch of a hand when the core is retrieved and a flow-like (micro-folding) pattern is observable on the cores due to many small microfaults with tiny displacements. Also, the gouge is very thin $(\sim 2 \mathrm{~mm})$. The clayey gouge deformation is a dark-grey or brown gouge zone within a fault zone. It contains some relic clasts within the gouge zone. Most importantly, the clayey gouge occupies a major amount of the volume within the fault zone. We will make more detailed explanations for these terms when we describe each major fault zone as examples.

Below, these ten fault zones are described in the terms of fault architecture and texture. Some of them are also described in detail by Sone et al. (2007) and Song et al. (2007). 
Yeh et al.

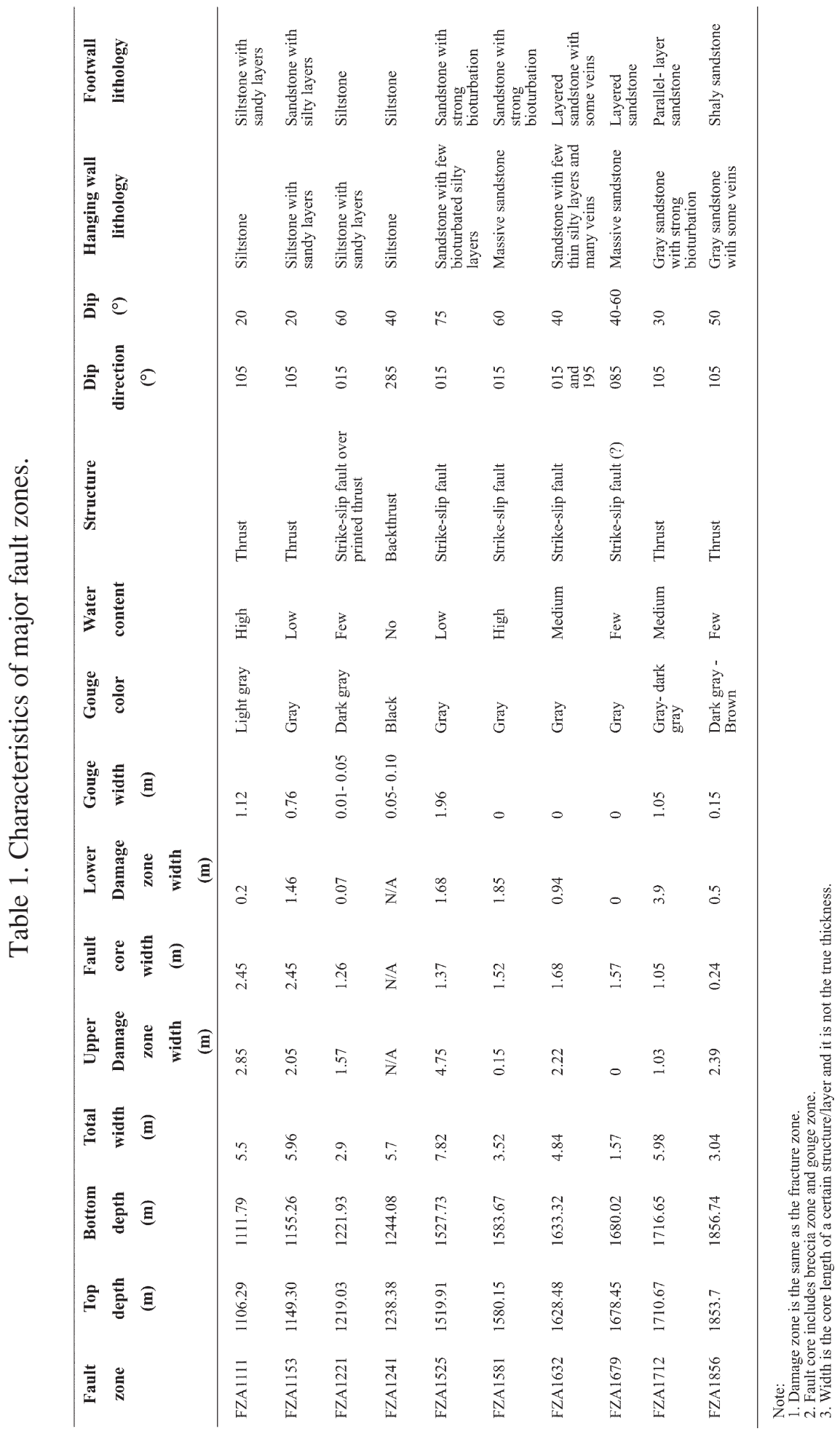




\subsubsection{FZA1111}

The FZA1111 is a bedding-slip thrust and has distinguished fracture deformation (Fig. 7). The fault zone developed within the siltstone-dominant region close to the lithological boundary between the siltstone-dominant region and a bioturbated sandstone region. Most cores from this fault zone were retrieved completely. The only loss might be in the Section 2 of Run 357. Also, a slight washout took place at the core surface around the top $8-18 \mathrm{~cm}$ of Run $358-2$ due to the uncompleted recovery of Run 357 . The bedding dip in the interval is disturbed by the FZA1111. From top to bottom, the FZA1111 contains a sequence of fracture zone, breccia zone, light-gray clayey gouge $(\sim 85 \mathrm{~cm}$ width), thin black gouge $(2-3 \mathrm{~cm})$, foliated gouge $(10 \mathrm{~cm})$, black gouge $(8 \mathrm{~cm})$, two fragile black ultra-cataclasite in the shape of hard disks $(\sim 2 \mathrm{~cm}$ width for each), clayey gouge $(13 \mathrm{~cm})$, breccia zone $(\sim 17 \mathrm{~cm})$, fracture zone and a return to wall rock. The upper black ultra-cataclasite layer was accidentally broken during core handling before photos were taken so that it was not shown on the slab-mode photo of Run 358-2. The
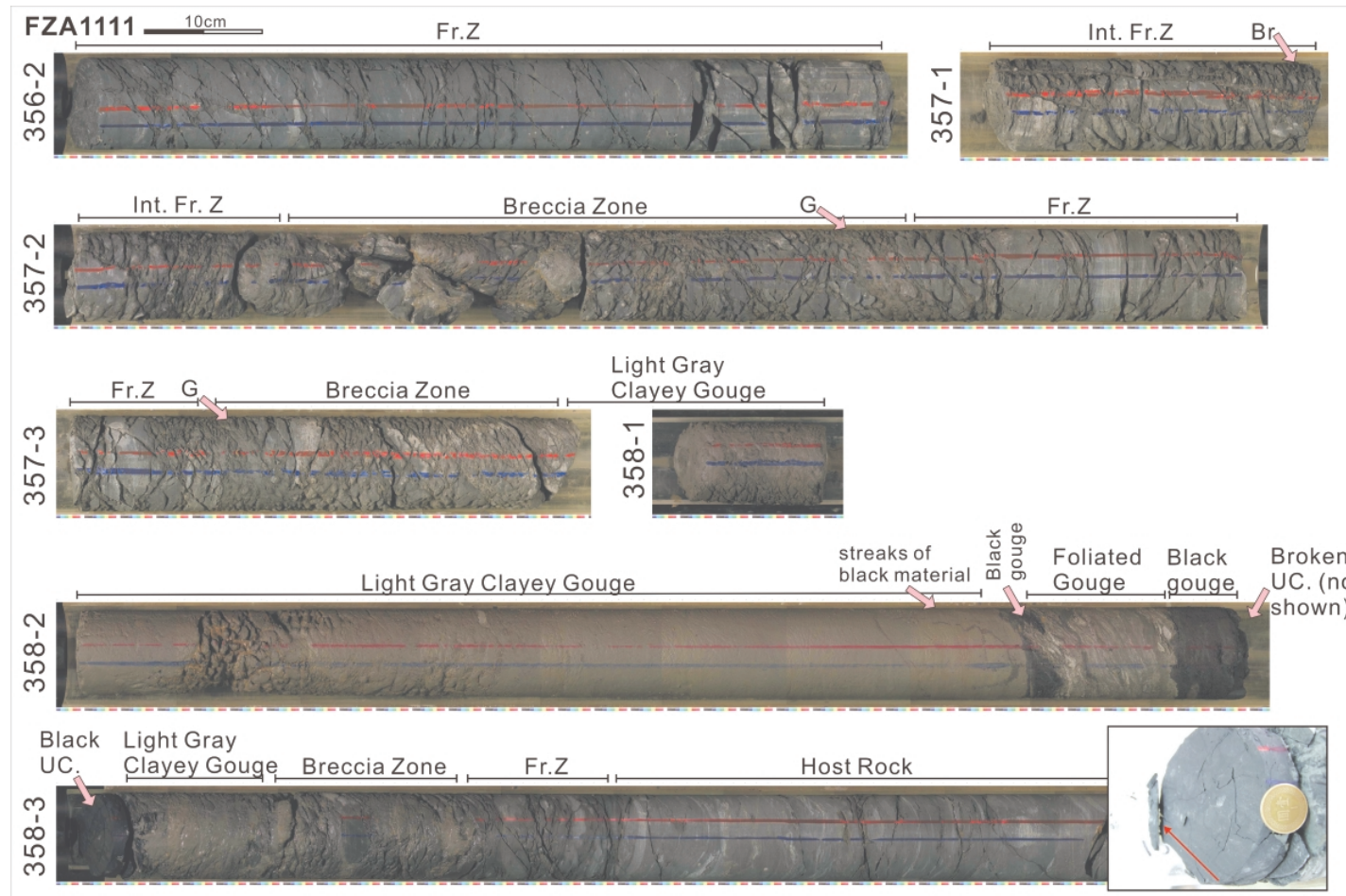

Fig. 7. Texture interpretation of FZA1111. The insert at the right-bottom corner displays the slickenside (red arrow) of $70^{\circ} \mathrm{SW}$ on the ultra-cataclasite. Fr.Z. stands for fracture zone, Int.Fr.Z. for intensive fracture zone, $\mathrm{Br}$ for breccia, $\mathrm{G}$ for gouge, $\mathrm{UC}$ for ultra-cataclasite. Pink arrow indicates the specific layer. 
lower ultra-cataclasite layer keeps its shape and includes a clear slickenside with a rake of $70^{\circ}$ SW. The orientation of this slickenside set is consistent with the slip direction of the Chi-Chi earthquake from seismic data inversion (Ma et al. 2001), suggesting the black ultra-cataclasite could be the product of slip deformation during the Chi-Chi earthquake. Furthermore, the dip of wet clayey black-white foliated gouge is steeper than that of surrounding black gouge. We interpreted that the foliated gouge and surrounding black gouge are the S-C structure. Considering the black ultra-cataclasite is the slip zone, the deformation interval and deformation intensity is much thicker and stronger at the hanging wall than that at the footwall. Therefore, FAZ1111 is an asymmetric fault zone with more damage in terms of fault architecture at the hanging wall of the thrusting event.

\subsubsection{FZA1153}

The FZA1153 is also a bedding-slip thrust and has a multiple fracture pattern (Fig. 8). The core was well retrieved within this interval. In terms of lithology, FZA1153 contains mainly sandy clasts and a high amount of fine sandy grains within the breccia zone and gouge zone. Also, in the top and bottom of this fault zone, there are several squeezed (compacted?) dark

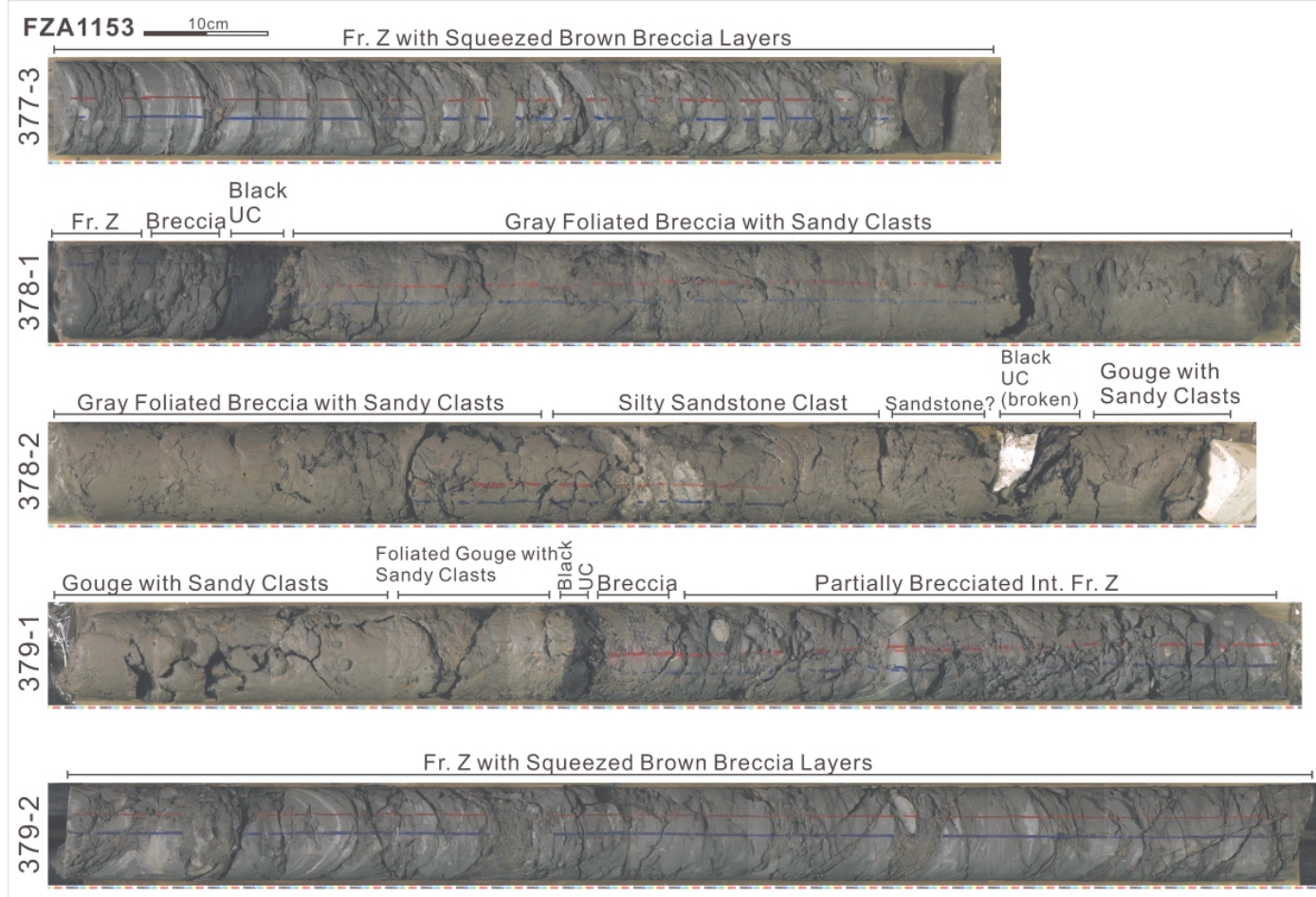

Fig. 8. Texture interpretation of FZA1153. The symbols as per Fig. 7. 
gray breccia layers. To the eye, water content in the gouge of the FZA1153 is less than that of the FZA1111. Three black ultra-cataclasite disks were observed in this fault zone but the second one was broken during core handling. Having three main slip zones within the FZA1153, the fracture pattern is not as systematic as the FZA1111. Furthermore, some N-dipping strikeslip faults postdated the thrusts in the foot wall to disturb the deformation pattern.

\subsubsection{FZA1221}

The FZA1221 is a complicated fault zone, within the siltstone-major interval, comprising older bedding-slip thrusts and younger strike-slip faults with a normal-slip component. Many gouge layers of $1 \mathrm{~cm}$ width were observed within this fault zone, including both thrusting and strike-slip faulting (Fig. 9). Most of these gouge layers were dry and brown, compacted by later deformation, suggesting the gouge was dewatered. Four layers of black ultra-cataclasite

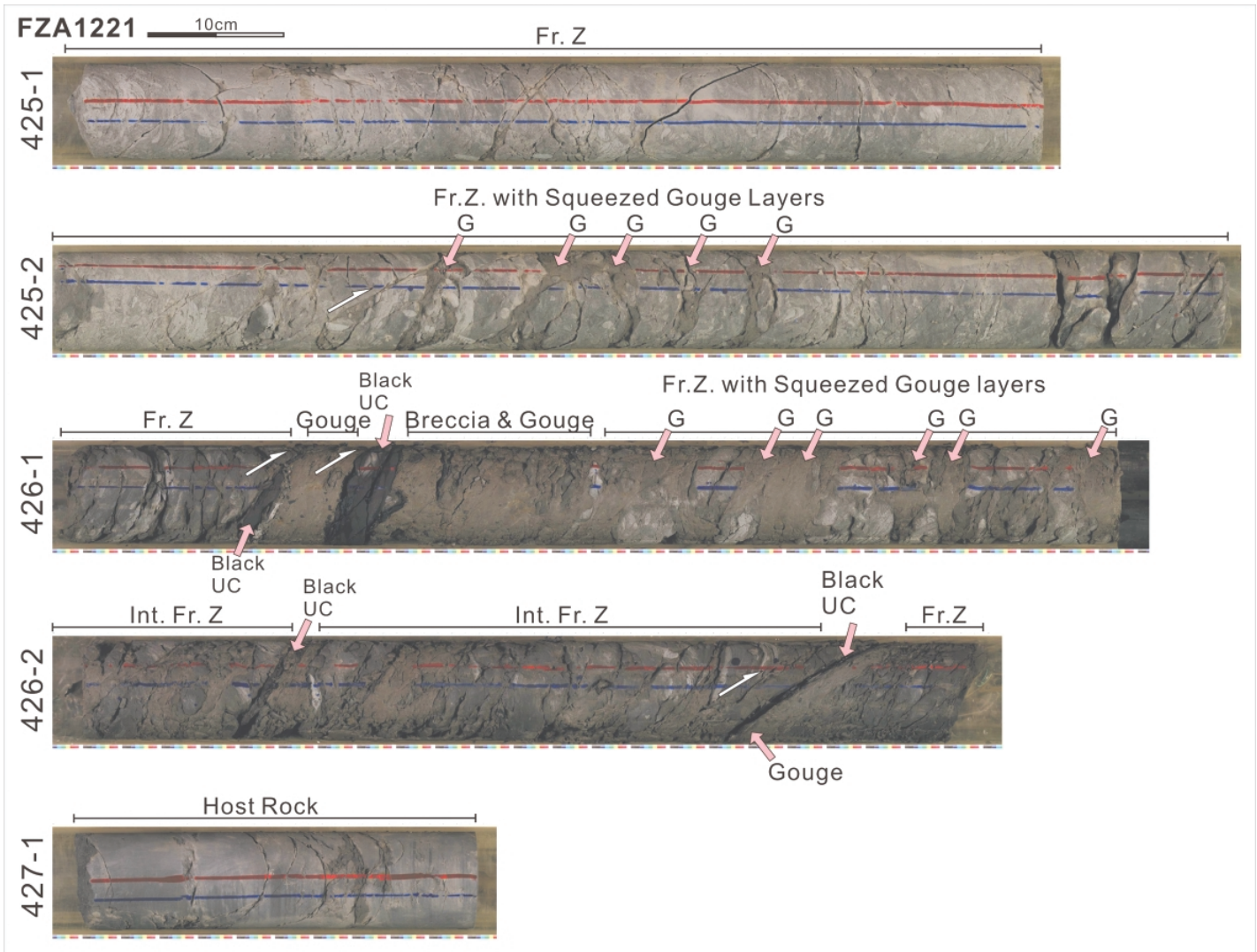

Fig. 9. Texture interpretation of FZA1221. The symbols as per Fig. 7. White arrows are representative of the shear sense. 
were found in this fault zone. The first and second black ultra-cataclasite layer and some dewatered brown gouge layers in the upper portion of the FZA1221 were parallel to the bedding but were cross-cut and dragged by strike-slip faulting $\left(015^{\circ} / 60^{\circ}\right)$ with normal-slip component, indicating that the thrusting event was overprinted by strike-slip deformation. The third and fourth black ultra-cataclasite layers were strike-slip deformation with some normal slip. Around the interval of the fourth ultra-cataclasite layer, the fault architecture downward displays a sequence of host rock, black ultra-cataclasite, gouge/breccia layer, fracture zone, and host rock. It shows asymmetric fault architecture with more damage in the footwall owing to normal slip deformation.

\subsubsection{FZA1241}

The FZA1241 is the only major fracture zone showing backthrust deformation in Hole-A (Fig. 10). This zone is a fracture zone, rather than a fault zone within the siltstone interval. No distinct breccia and gouge is observed. Oppositely, many bedding-parallel fractures and backthrust-like fractures $\left(285^{\circ} / 40^{\circ}\right)$ are observed. We interpret that the thrust and backthrust
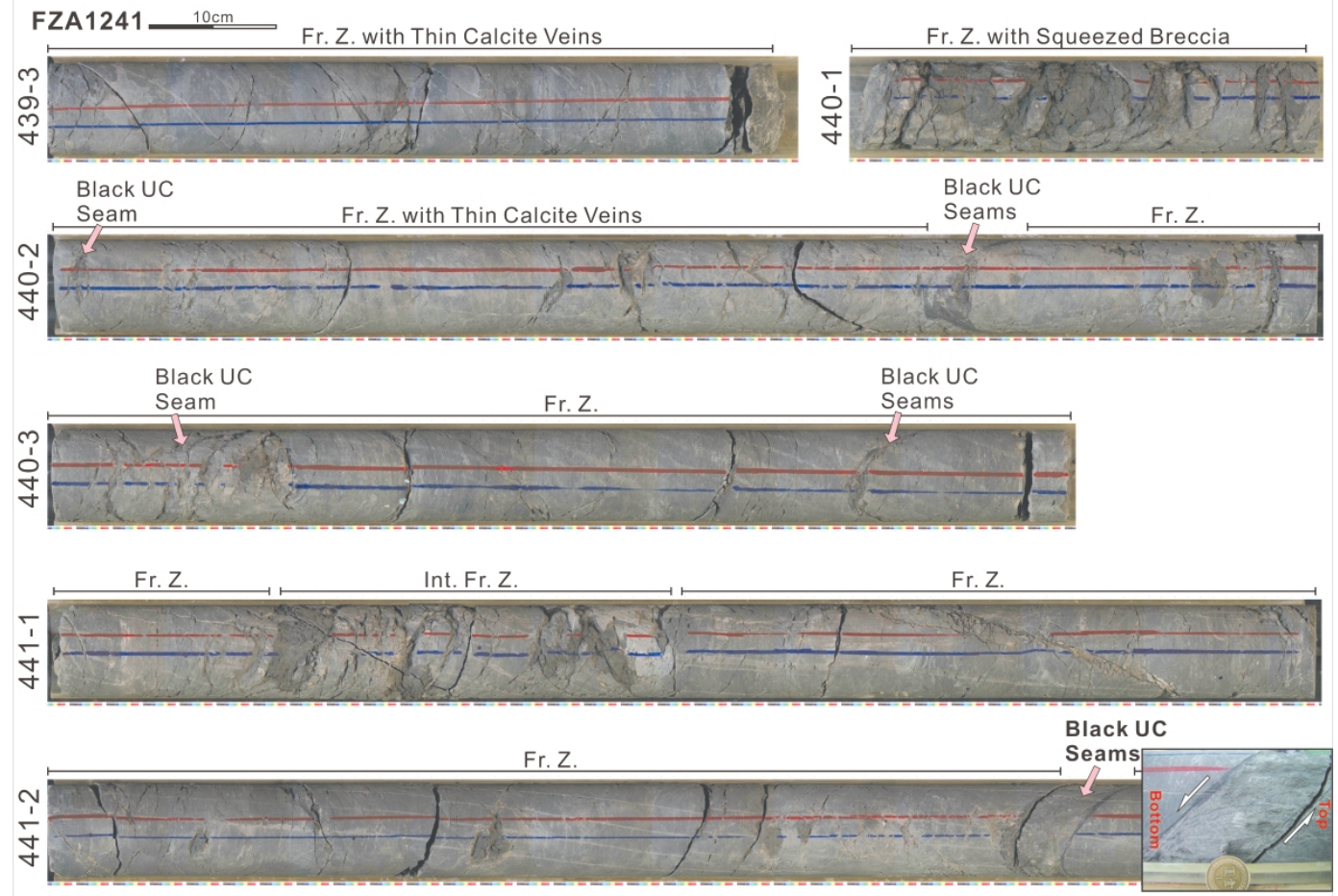

Fig. 10. Texture interpretation of FZA1241. The backthrust is displayed by drag folding of thin ultra-cataclasite seams in the insert. The symbols as per Fig. 7. 
are conjugated in the larger scale. Within the backthrusts, many thin black ultra-cataclasite seams are found. They collocated into a dense slip zone with drag folds with reverse movement in one fracture (Fig. 10, insert). The appearance of these thin ultra-cataclasite seams is very similar to the ultra-cataclasite disks of the shallower major fault zones we mentioned above. However, no thin ultra-cataclasite seam is observed within any bedding-parallel fracture around the depth interval of the FZA1241.

\subsubsection{FZA1525}

The FZA1525 is a high angle strike-slip fault zone with strong clayey gouge deformation in the sandstone-dominant interval (Fig. 11). The core within this fault zone was recovered in good condition without any significant loss. The deformation boundary is sharp with an orientation of $015^{\circ} / 75^{\circ}$, even though there might be a sampling bias due to the small angle between the vertical coring direction and the high dip of this strike-slip fault zone. The observation, that the gouge zone is next to host rock and no much distinct fracture zone and breccia zone is
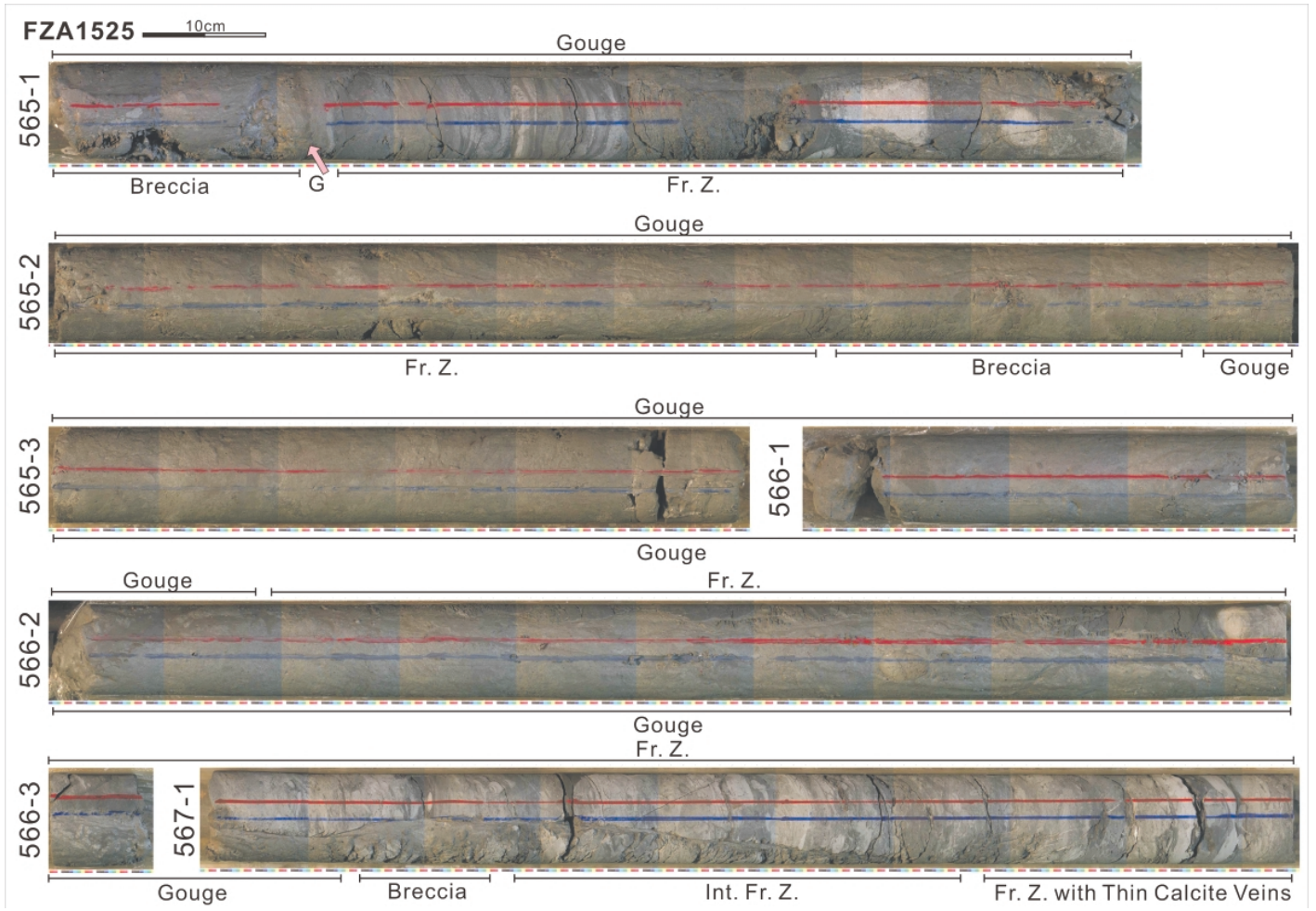

Fig. 11. Texture interpretation of FZA1525. It is a clayey gouge deformation. The symbols as per Fig. 7. 
observed between them, supports the interpretation of the sharp deformation boundary. However, within the light-brown gouge zone (dewatering?), many gray sandy clasts $(0.5-1.5 \mathrm{~cm}$ width), similar to the lithology of host rock, are still found, suggesting relic clasts of host rock survive with strong deformation of clayey gouge zone.

\subsubsection{FZA1581}

The FZA1581 is a strike-slip fault zone with soft-rock deformation in a sandstone interval (Fig. 12). The recovered cores are not in good condition; they were fractured and broken during coring and core handling due to high deformability. Some veins were filled within fissures in the intact and deformed portions. Although the deformed fracture zone and breccia zone occupy a major portion of this fault zone, four thin dark-brown gouge layers $(0.5-1 \mathrm{~cm}$ width) with an orientation of $015^{\circ} / 60^{\circ}-70^{\circ}$ were found. These gouge layers were straight but some brown streaks around them are wavy; obvious displacement on the beddings and pre-
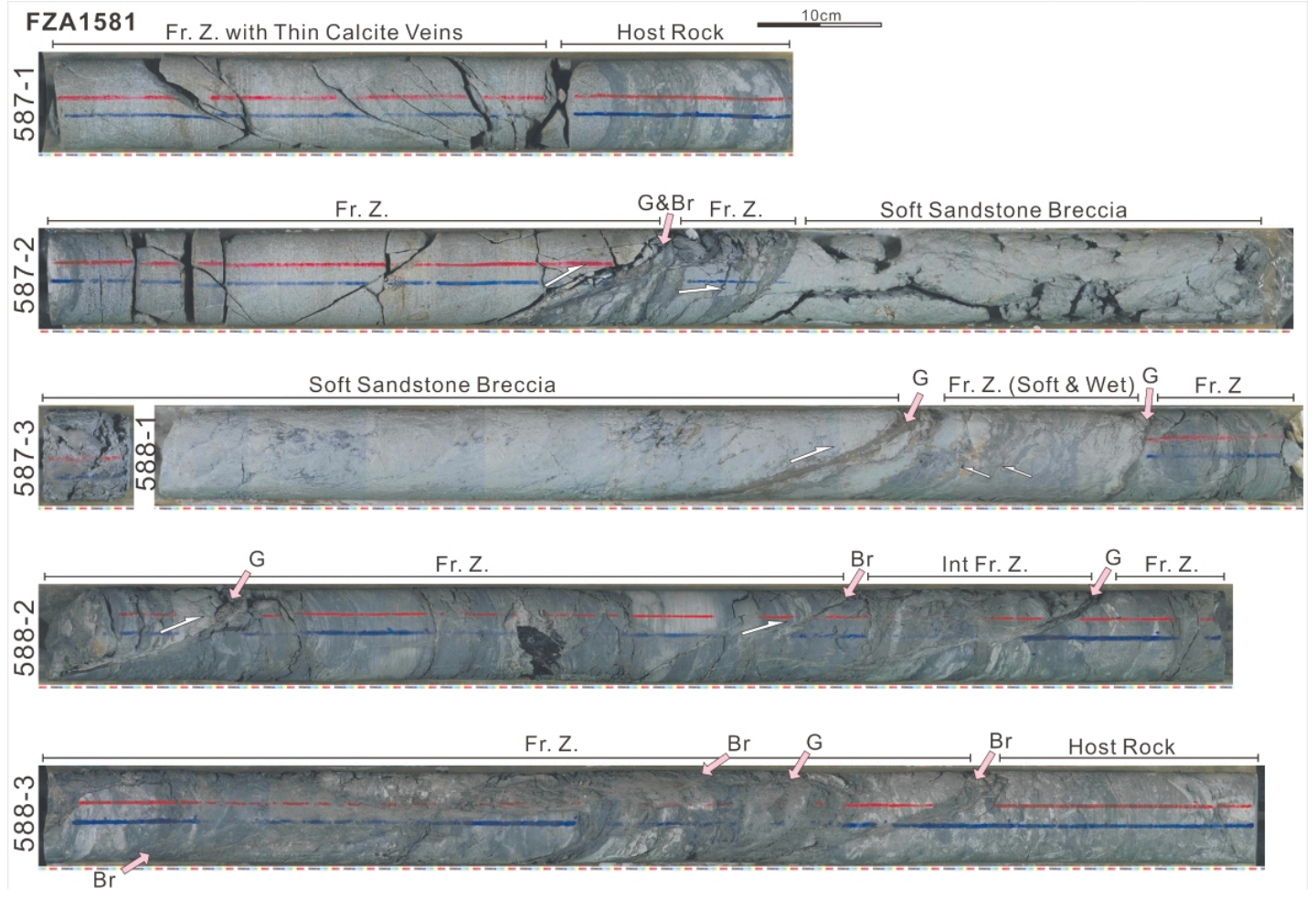

Fig. 12. Texture interpretation of FZA1581. The clayey gouge deformation within this fault is very typical. The symbols as per Fig. 7. White arrows are representative of the shear sense. 
existing gouge layers is observed, suggesting those thin straight gouge layers reflect the most recent deformation within the FZA1581. Moreover, tiny displacements on microfaults are obvious between the gouge layers of Run 588-1 and a noticeable displacement pattern can be recognized with displacement direction of $195^{\circ} / 50^{\circ}$. As a result, we interpret two strike-slip faults of opposite dip directions being conjugated and displacement along $015^{\circ} / 60^{\circ}$ being dominant within this fault zone.

\subsubsection{FZA1632}

The FZA1632 is a typical of what we called "soft-rock deformation" in the sandstone interval and it has no distinctive slip orientation (Fig. 13). The core condition was poor, as in FZA1581. Some intensive fine veins with web geometry are observed in Run 611-3. Many thin dark-gray gouge streaks are displaced as microfolds along the conjugated microfaults of strike-slip fault orientation in Runs 611-1 and -2, suggesting that no central slip direction is detectable in these small conjugated strike-slip faults within this fault zone, even though some distinct slickensides are observed. Besides, three thin dark-gray straight gouge layers $(2-3 \mathrm{~mm})$

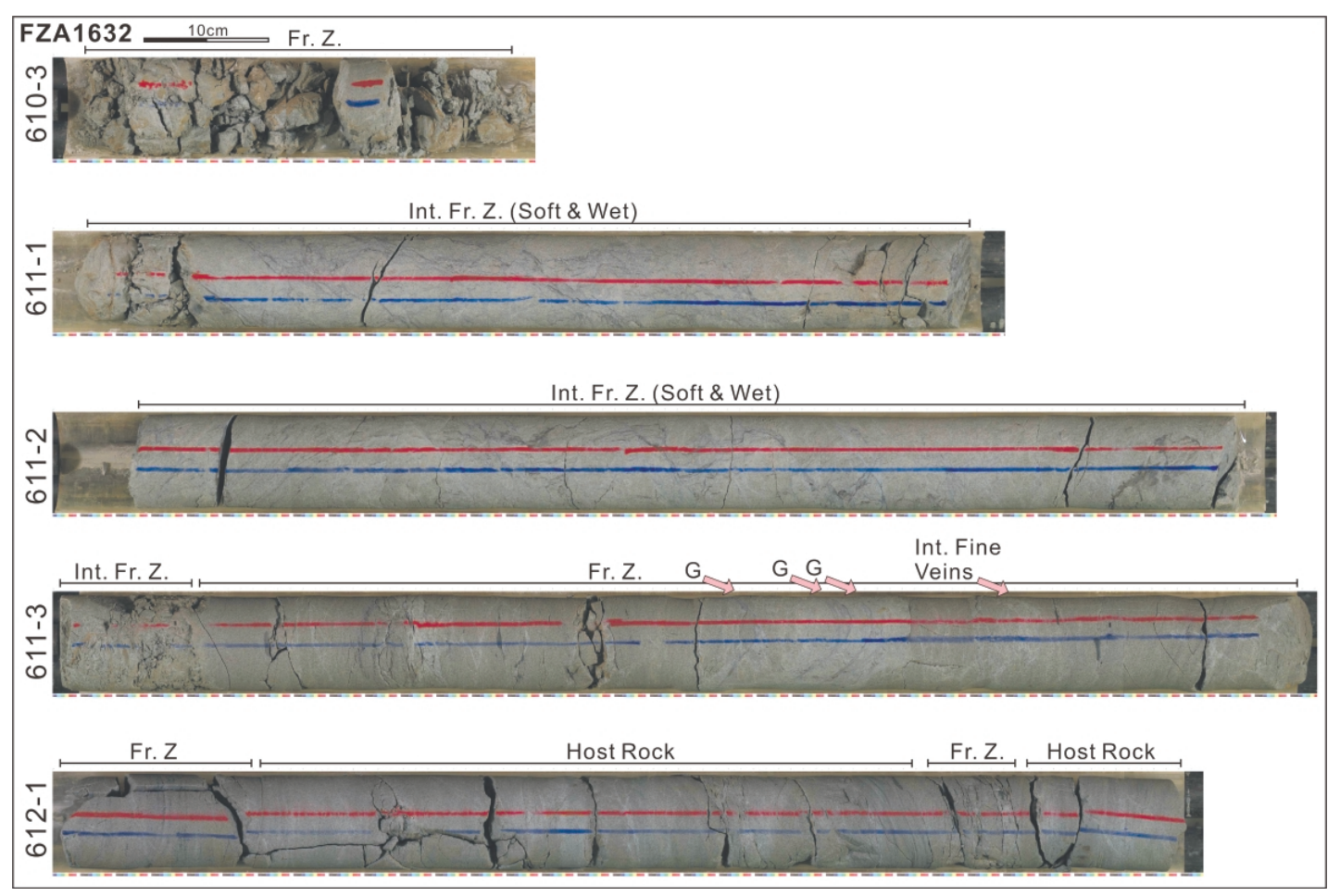

Fig. 13. Texture interpretation of FZA1632. It is typical soft-rock deformation (the details in the context). The symbols as per Fig. 7. 
of bedding-parallel orientation in Run 611-3 were found. Within the interval of small conjugated faults, some residual sedimentary structures were still found; this is consistent with the observation of tiny displacement on these faults.

\subsubsection{FZA1679}

The FAZ1679 is a fragile fault zone with soft-rock deformation in the sandstone interval (Fig. 14). The core condition was bad since the core was dismembered and was influenced by the heat induced by coring as a thin black membrane covered the cores. Although no obvious slip or microfold was observed within the soft fracture zone, some fractures of $075^{\circ}-085^{\circ} / 40^{\circ}-60^{\circ}$ were found. Also, a few thin veins ( $\sim 1 \mathrm{~mm}$ width) and black gouge layers $(\sim 2 \mathrm{~mm}$ width) of $085^{\circ}$ dip direction and $60^{\circ}$ dip were discovered in Run 637-2. Therefore, we believed that the FZA1679 is a strike-slip fault zone with an orientation of $075^{\circ}-085^{\circ} / 40^{\circ}-60^{\circ}$. It is soft-rock deformation; however, the rock is too deformable, and fragile to keep the core of this fault zone integration intact after cores were retrieved for further on-site examination.

\subsubsection{FZA1712}

The FZA1712 is a bedding-parallel reverse fault zone with a clayey gouge deformation within the sandstone interval (Fig. 15). The core was recovered well within the gouge zone;

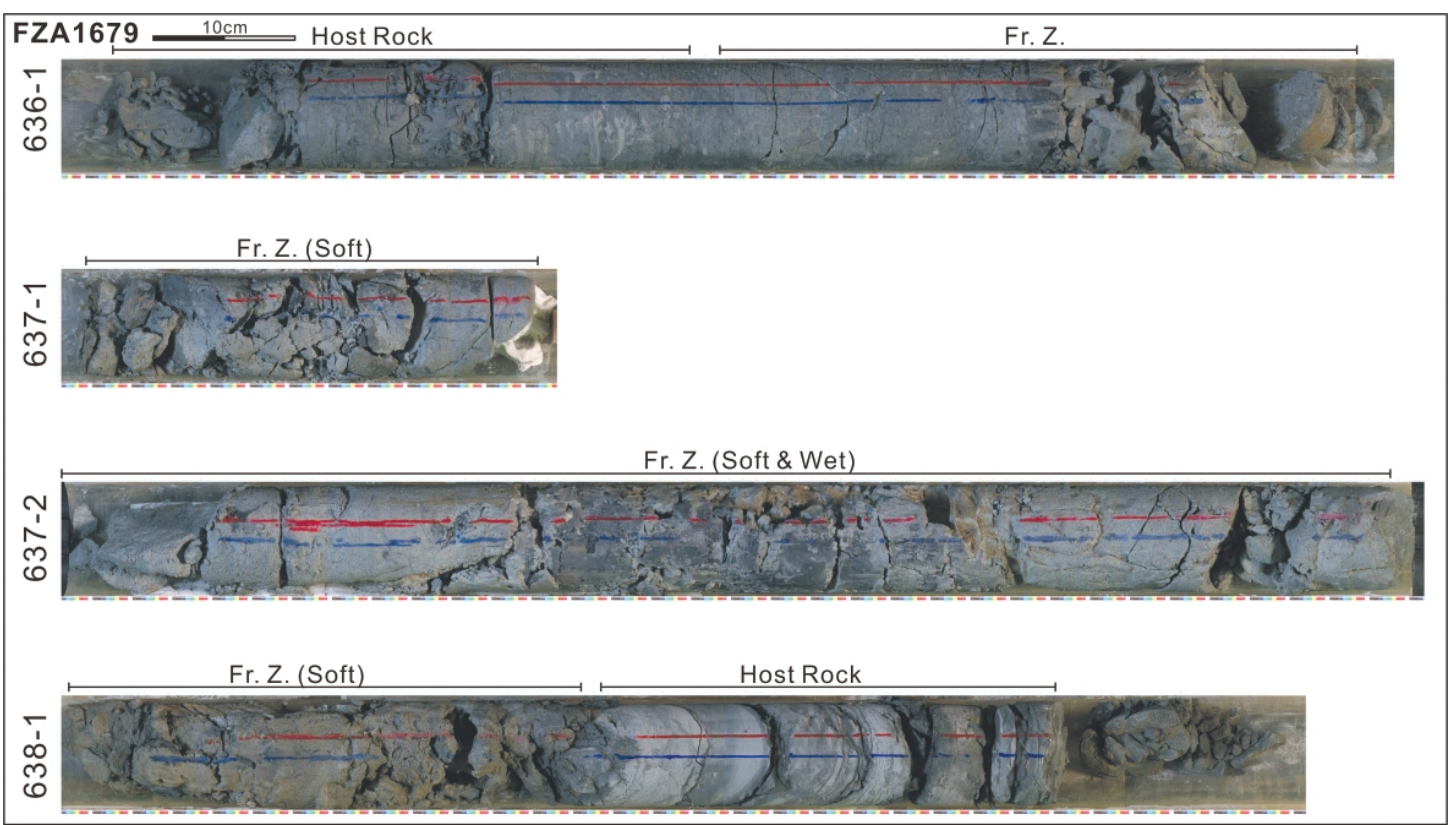

Fig. 14. Texture interpretation of FZA1679. The symbols as per Fig. 7. 


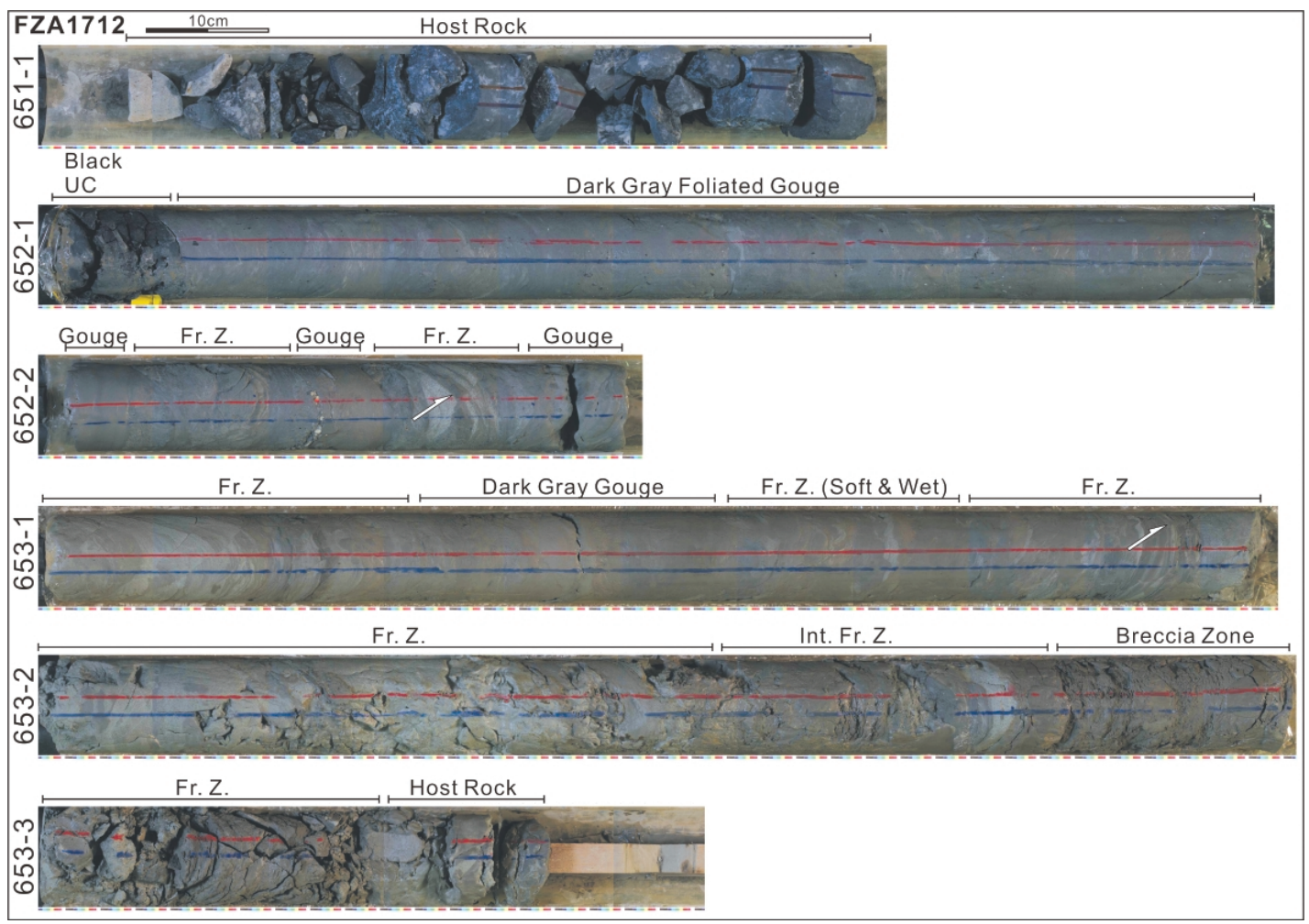

Fig. 15. Texture interpretation of FZA1712. T The symbols as per Fig. 7. White arrows are representative of the shear sense.

but, there was damage on the core above and below the gouge zone during coring and core handling, perhaps partly due to the fragile and fractured lithology. One distinctive black ultracataclasite was found in the top of Run 652-1 but it was broken. Also, we were not sure how much loss of the core between Run 651-1 and 652-1 occurred. As a result, the complete architecture of deformation components in this fault zone cannot be determined. However, clayey gouge deformation with obvious bedding-parallel foliation is still remarkable. Furthermore, several clayey gouge zones are intermittent with fracture zones. Contrary to bedding-slip within the clayey gouge, strike-slip faults of $015^{\circ} / 50^{\circ}$ with normal-slip are dominant within the fracture zones. Because clayey gouges crosscut the strike-slip faults, the deformation stage of strike-slip faulting is older than the development of clayey gouge.

\subsubsection{FZA1856}

The FZA1856 is a bedding-parallel reverse fault zone with a fracture deformation in the sandstone/shaly sandstone interval (Fig. 16). The condition of the recovered core was not 

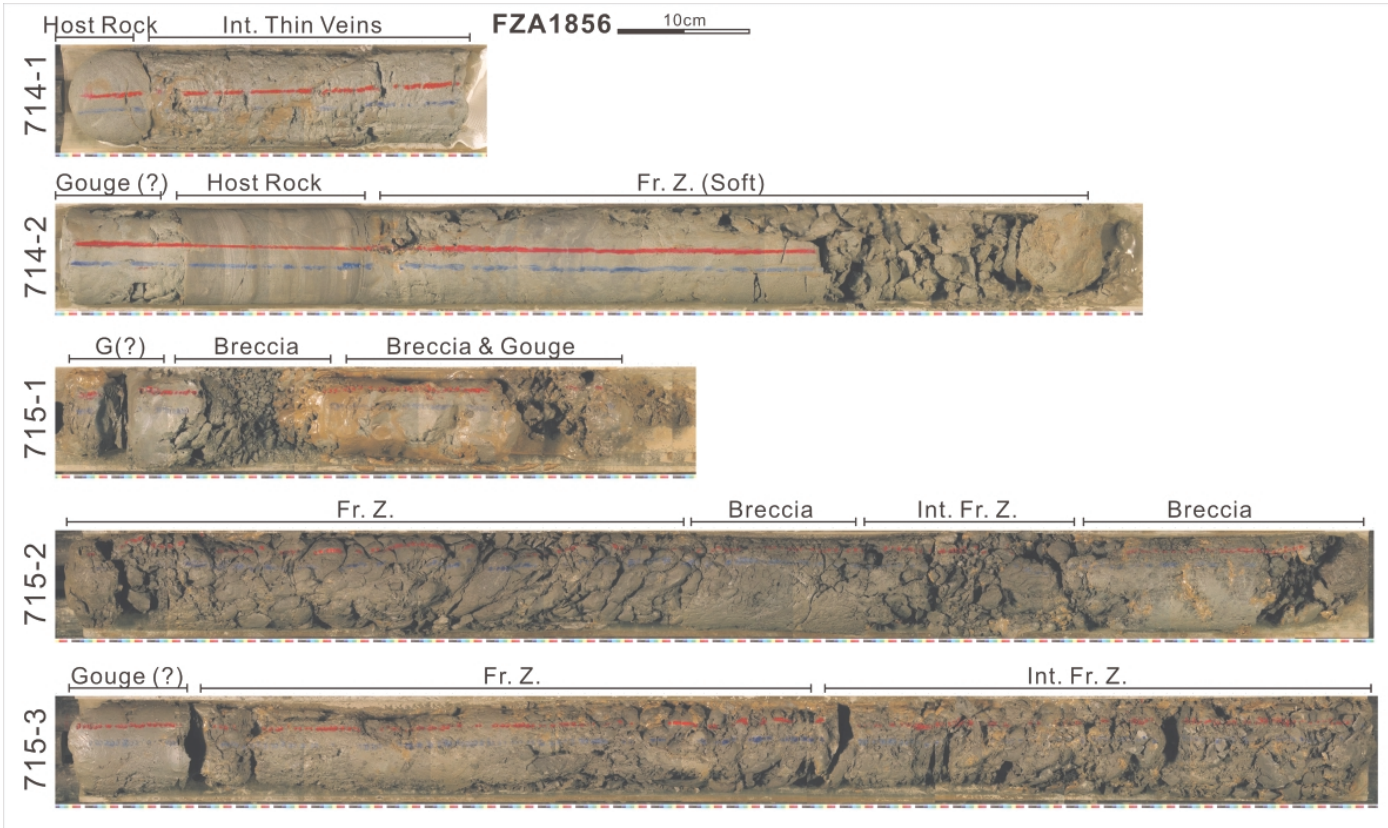

Breccia, Foliated Breccia, Int. Fr. Z. $\longmapsto \longmapsto$ Fr. Z. Host Rock

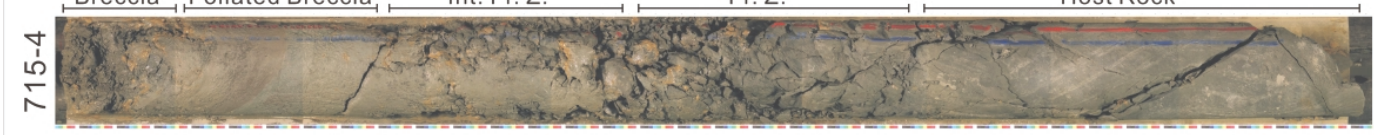

Fig. 16. Texture interpretation of FZA1856. The symbols as per Fig. 7.

good. Some damage and washout on this fault zone can be clearly observed. Some disturbances on the bedding dip were also perceptible around this fault zone. The bedding dip of about $60^{\circ}$ decreased with depth when approaching the fault zone, reached the dip of $30^{\circ}$ at the fault zone and changed back to the original dip after the FZA1856. Intensive thin veins developed in the top of this fault zone. Although deformation components are sporadic, the main slip zone is located within the foliated breccia of Run 715-4. The color of the FZA1856 is brown/dark brown, suggesting this fault zone might be dewatered (older?).

\section{DISCUSSION}

\subsection{The Candidate for the Chi-Chi Earthquake Rupture}

Identification of the Chi-Chi earthquake rupture on the cores of the TCDP is a fundamental issue before studying the earthquake generation and the rupture mechanism on the core samples. First, on a regional scale, results from the high-resolution shallow seismic reflection indicate that the Chelungpu fault zone is at a depth of $\sim 1200 \mathrm{~m}$ with $10 \%$ error beneath the 
drill site (Wang et al. 2002, 2004). In other words, the potential candidates will be in the range of 1100 - 1300 m, i.e., one of the fault zones within the Chelungpu Fault System (FZA1111, FZA1153, FZA1221, and FZA1241). Second, as per the descriptions of fault zones (Section 4.3), FZA1241 is a backthrust and FZA1221 is strike-slip fault, indicating that both fault zones can be ruled out from the candidate list. As a result, the FZ1111 and FZ1153 are the most likely candidates of the fault zone which slipped during the Chi-Chi earthquake.

Third, on a local scale, without further detailed examination on the multiple slip zones of the FZA1153, no evidence to for or against this possibility for the Chi-Chi earthquake rupture could be found. In contrast, the S-C texture of the FZA1111 implies that there is high-strain concentrated within the lower black gouge and/or ultra-cataclasite. Furthermore, the slickenside with a rake of $70^{\circ} \mathrm{SW}$ on the fragile black ultra-cataclasite within the bottom of FZ1111 is consistent with the slip direction inferred from seismic inversion (Ma et al. 2001), suggesting the black ultra-cataclasite could be the product of slip deformation during the Chi-Chi earthquake. Fourth, FZ1111 shows anomalies of low resistivity, low density, low Vp and Vs and high Poisson's ratio (Hung et al. 2007). Also, if the amount of water content is consistent with high activity of fault slip, the light-gray color of the gouge within the FZA1111, compared with the dark-grey/brown color within the FZA1153 gouge zone implies that FZA1111 is more active than the FZA1153. Consequently, we interpret that the FZA1111 is the more probable slip zone for the Chi-Chi earthquake.

\subsection{The Location of the Sanyi Fault}

The location of the Sanyi fault zone beneath the Chelungpu fault zone in the drill site can provide an important constraint on regional tectonics and displacement regarding the fault separation and segmentation. The regional distribution of the fault zones indicates that the northern Chelungpu fault zone should climb up onto the southern Sanyi fault zone in the northern Taichung basin (Yue et al. 2005). However, there is no surface outcrop to show their relation in the northern Taichung basin. The lithologic column of $1712-2003 \mathrm{~m}$ depth in TCDP Hole-A is interpreted as the Cholan Formation. Furthermore, a unique oyster layer as an aspect of Cholan Formation around $1754 \mathrm{~m}$ was found. Therefore, the Cholan Formation seems to re-appears around $1754 \mathrm{~m}$ and is overlaid by the Kueichulin Formation (Fig. 4). Consistently, the significant fault zone, FZA1712, is observed as a reverse fault with thick foliated gouge. Additionally, the data from down-hole physical logging display a significant difference existing above and below FZA1712 (Hung et al. 2007). Thus, the evidence from lithology, fault zone location and physical log data indicates that the Kueichulin Formation overthrusts the Cholan Formation at a depth of $1712 \mathrm{~m}$ by the FZA1712 (the Sanyi fault zone), which is about $600 \mathrm{~m}$ beneath the Chelungpu fault zone (Fig. 1b).

\subsection{Lithological Influence on the Development of Fault Zones}

Lithology is one of the main factors influencing the development of fault zones, including the location and the architectural pattern. For fault zone location, it is obvious from our observation that most of fault zones developed on the finer-grain side of the lithologic boundary, instead of right at the boundary. For example, in the thrusts of FZA1111 and FZA1153, the 
grain size of the hanging wall is finer than that of the footwall and more damage is also evident at the hanging wall. On the contrary, this feature of lithology is opposite in FZA1221 for the sinistral fault with normal slip, i.e., the grain size of the hanging wall is coarser. For FZA1241 (the backthrust with dry ultra-cataclasite seams), the lithology of the hanging wall and footwall are the same. Moreover, the fault zones within the Sanyi Fault System developed within the lithology having finer-grain parts and being close to the lithologic boundary when compared with nearby regions.

Regarding the fault architecture of the major fault zones, there is a distinguishing difference between the Chelungpu Fault System and the Sanyi Fault System, probably due to a discrepancy of the protolith. Generally, the architecture of fault zones within the Chelungpu Fault System encloses distinct fracture deformation (FZA1111, FZA1153, and FZA1221) and a fracture zone with aggregates of hard ultra-cataclasite seams (FZA1241). In contrast, the architecture of fault zones within the Sanyi Fault System contains clayey-gouge deformation (FZA1525, FZA1712), soft-rock deformation (FZA1581, FZA1632, and FZA1679) and distinct fracture deformation (FZA1856). As noticed (Table 1), the Chelungpu Fault System developed within the Chinshui Shale and the Sanyi Fault System is mainly within the Kueichulin Formation and Cholan Formation. Thus, lithology-related physical properties, such as strength, porosity and water content, between siltstone and sandstone could play the main roles in constructing fault architecture.

In detail, the architectural pattern of fault zones with fracture deformation is highly asymmetric. For example, regarding a thrusting fault zone from top to bottom, such as the FZA1111, the architectural patterns change from fracture zone to intense fracture zone, breccia zone, gouge zone, black ultra-cataclasite, and finally, a thin layer of breccia zone or fracture zone. Thus, the damaged zone is thicker above the fault core than below, and also the lower boundary appears sharper compared to the broad upper transient boundary. Another notable feature of the fault zones is that usually there is a thin layer of ultra-cataclasite at the bottom part of the fault core. Conversely, the opposite pattern is found in the normal slip zone. For instance, the architecture of the FZA1221 is opposite the shallower reverse fault zones. That is, the ultra-cataclasite and gouge are at the upper end, whilst the breccia zone and fracture zone are at the deeper end of the fault zone. The asymmetric architecture of the fault zone is also reported in the Nankai trough drilling (Taira et al. 1992). Recently, studies based on numerical simulation showed that a wrinkling-like pulse could be the driving force in the development of asymmetric fault zones (Ben-Zion and Sammis 2003).

\section{SUMMARY}

The Taiwan Chelungpu-fault Drilling Project (TCDP) provides a unique opportunity to study the rupture mechanism of the Chi-Chi earthquake in the northern segment and the location of the Sanyi fault zone. Based on the core observation at 500 - $2003 \mathrm{~m}$ down from TCDP Hole-A, the lithostratigrphic boundaries have been identified but need to be further confirmed by biostratigrapy and magnetostratigraphy studies. The recognized lithostratigraphies are Cholan Formation (500 - 1027 m), Chinshui Shale (1027 - 1268 m), Kueichulin Formation (1268 $1712 \mathrm{~m}$ ) and Cholan Formation (1712 - $2003 \mathrm{~m})$. 
Although the deformation structure within the Hole-A core is rather complicated, five groups still can be differentiated, including reverse fault, left-lateral and right-lateral faults, backthrust and normal faulting. The left-lateral strike-slip faulting is interpreted as the oldest deformation, which occurred earlier than the reverse faulting of the Chi-Chi earthquake slip. Furthermore, ten major fault zones have been observed between 500 and $2003 \mathrm{~m}$. They can be grouped as the Chelungpu Fault System of about $100 \mathrm{~m}$ wide within the Chishui Shale (FZA1111, FZA1153, FZA1221, and FZA1241) and the Sanyi Fault System of about $300 \mathrm{~m}$ wide within the Kueichulin and Cholan Formations (FZA1525, FZA1581, FZA1632, FZA1679, FZA1712, and FZA1856). After compiling with other currently available data, we interpret that FZ1111 is the most likely candidate for the Chi-Chi earthquake rupture. The Sanyi fault zone is located about $600 \mathrm{~m}$ beneath the Chelungpu fault zone and corresponds to FZA1712, based on the deformation structure, lithostratigraphy, fossil and logging data.

The architecture of major fault zones based on the deformation textures can be classified as the fracture deformation, clayey-gouge deformation and soft-rock deformation. Fracture deformation is dominant within the Chelungpu Fault System and two other architectures prevail in the Sanyi Fault System. Specifically, the fracture-deformation architecture is asymmetric, depending on the shear sense of the fault zone. From the distribution of fault zones along the core, the lithology or rock strength could be a major factor controlling the location and architectural pattern for fault zone development.

Acknowledgements We especially thank Dr. J. H. Wang (Academia Sinica) and Prof. Y. B. Tsai (National Central University) for directing this drilling project. Thanks are also extended to assistants and students of the National Central University, National Taiwan University and Chinese Culture University for their tremendous help doing various kinds of onsite work. Chia-Yu Lu and Manoj Jaiswal are thanked for the comments and grammar corrections they made. We are grateful to Jian-Cheng Lee and an anonymous reviewer for improving the manuscript. This research was supported by IFREE, JAMSETC, Japan and Taiwan National Science Council grant NSC-95-2811-M-002-012. This is Taiwan Earthquake Research Center Contribution 00010.

\section{REFERENCES}

Angelier, J., 1994: Fault slip analysis and palaeostress reconstruction. In: Hancock, P. L. (Ed.), Continental Deformation, Pergamon Press, New York, 53-100.

Angelier J., J. C. Lee, H. T. Chu, and J. C. Hu, 2003: Three-dimensional deformation along the rupture trace of the September $21^{\text {st }}, 1999$, Taiwan earthquake: A case study in the Kuangfu school. J. Stru. Geol., 25, 345-350.

Barrier, E., and J. Angelier, 1986: Active collision in eastern Taiwan: The Coastal Range. Tectonophysics, 125, 39-72.

Ben-Zion, Y., and C. G. Sammis, 2003: Characteristics of fault zones. Pure Appl. Geophys., 160, 677-715.

Bonilla, M. G., 1977: Summary of Quaternary faulting and elevation changes in Taiwan. Mem. Geol. Soc. China, 2, 43-55. 
Biq, C., 1972: Dual trench structure in the Taiwan-Luson region. Proc. Geol. Soc. China, 15, 65-75.

Bowin, C., R. S. Lu, and C. S. Lee, 1978: Plate convergence and accretion in Taiwan-Luzon region. AAPG Bull., 62, 1645-1672.

Chai, H. T., 1972: Structure and tectonic evolution of Taiwan. Am. J. Sci., 272, 389-422.

Chang, S. L., 1971: Subsurface geologic study of the Taichung basin. Petrol. Geol. Taiwan, 8, 21-45.

Chester, F. M., J. P. Evans, and R. L. Biegel, 1993: Internal structure and weakening mechanism of the San Andreas fault. J. Geophys. Res., 98, 771-786.

Davis, D., J. Suppe, and F. A. Dahlen, 1983: Mechanics of fold-and-thrust belts and accretionary wedges. J. Geophys. Res., 88, 1153-1172.

Heermance, R., Z. K. Shipton, and J. P. Evans, 2003: Fault structure control on fault slip and ground motion during the 1999 rupture of the Chelung fault, Taiwan. Bull. Seismol. Soc. Am., 93, 1034-1050.

Ho, C. S., 1986: A synthesis of the geologic evolution of Taiwan. Tectonophysics, 125, 1-16.

Ho, C. S., 1988: An Introduction to the Geology of Taiwan-Explanatory Text of the Geologic Map of Taiwan, $2^{\text {nd }}$ Ed., Cent. Geol. Surv., MOEA, Taipei, Taiwan, ROC, 163 pp.

Hung, J. H., H. P. Zhan, D. V. Wiltschko, and P. Feng, 2002: Geodetically observation surface displacements of the 1999 Chi-Chi earthquake near southern termination of the Chelungpu fault. Terr. Atmos. Ocean. Sci., 13, 355-366.

Hung, J. H., Y. H. Wu, E. C. Yeh, J. C. Wu, and TCDP Scientific Party, 2007: Subsurface structure, physical properties, and fault zone characteristics in the scientific drill holes of Taiwan Chelungpu-fault Drilling Project. Terr. Atmos. Ocean. Sci., 18, 271-293, doi: 10.3319/TAO.2007.18.2.271(TCDP).

Kao, H., R. Y. Chen, and C. H. Chang, 2000: Exactly where does the 1999 Chi-Chi earthquake in Taiwan nuclear?-Hypocenter relocation using the master station method. Terr. Atmos. Ocean. Sci., 11, 567-580.

Kao, H., and W. P. Chen, 2000: The Chi-Chi earthquake sequence: Active out-of-sequence thrust faulting in Taiwan. Science, 288, 2346-2349.

Lee, J. C., Y. G. Chen, K. Sieh, K. Mueller, W. S. Chen, H. T. Chu, Y. C. Chan, C. Rubin, and R. Yates, 2001: A vertical exposure of the 1999 surface rupture of the Chelungpu fault at Wufeng, western Taiwan: structural and paleoseismic implications for an active thrust fault. Bull. Seismol. Soc. Am., 91, 914-929.

Lee, J. C., H. T. Chu, J. Angelier, Y. C. Chen, J. C. Hu, C. Y. Lu, and R. J. Rau, 2002: Geometry and structure of northern surface ruptures of the $1999 \mathrm{M}_{\mathrm{w}}=7.6$ Chi-Chi Taiwan earthquake. J. Struct. Geol., 24, 173-192.

Lee, Y. H., M. L. Hsieh, S. D. Lu, T. S. Shi, W. Y. Wu, Y. Sugiyama, T. Azuma, and Y. Kariya, 2003: Slip vectors of the surface rupture of the 1999 Chi-Chi earthquake, western Taiwan. Struct. Geol., 25, 1917-1931.

Liu, C. S., I. L. Huang, and L. S. Teng, 1997: Structural features off southwestern Taiwan. Mar. Geol., 137, 305-319.

Lu, C. Y., and K. J. Hsu, 1992: Tectonic evolution of the Taiwan mountain belt. Petrol. Geol. Taiwan, 27, 21-46. 
Ma, K. F., C. T. Lee, Y. B. Tasi, T. C. Shin, and J. Mori, 1999: The Chi-Chi Taiwan earthquake: large surface displacements on inland thrust fault. EOS Trans. AGU, 80, 605-611.

Ma, K. F., T. R. Song, S. J. Lee, and H. I. Wi, 2000: Spatial slip distrubition of the September 21, 1999, Chi-Chi, Taiwan earthquake $\left(\mathrm{M}_{\mathrm{w}}\right.$ 7.6) - Inverted from teleseismic data. Geophys. Res. Lett., 27, 3417-3420.

Ma, K. F., J. Mori, S. J. Lee, and S. B. Yu, 2001: Spatial and temporal distribution of slip for 1999 Chi-Chi, Taiwan, earthquake. Bull. Seismol. Soc. Am., 91, 1069-1087.

Meng, C. Y., 1963: San-I overthrust. Petrol. Geol. Taiwan, 2, 1-20.

Pathier, E., B. Fruneau, B. Deffontaines, J. Angelier, C. P. Chang, S. B. Yu, and C. T. Lee, 2003: Coseismic displacements of the footwall of the Chelungpu fault caused by the 1999, Taiwan, Chi-Chi earthquake from In SAR and GPS data. Earth Planet. Sci. Lett., 212, 73-88.

Sibson, R. H., 1977: Fault rocks and fault mechanisms. J. Geol. Soc. London, 133, 191-213.

Sone, H., E. C. Yeh, T. Nakaya, J. H. Hung, K. F. Ma, C. Y. Wang, S. R. Song, and T. Shimamoto, 2007: Mesoscopic structural observations of cores from the Chelungpu Fault System, Taiwan Chelungpu-fault Drilling Project Hole-A, Taiwan. Terr. Atmos. Ocean. Sci., 18, 359-377, doi: 10.3319/TAO.2007.18.2.359(TCDP).

Song, S. R., L. W. Kuo, E. C. Yeh, C. Y. Wang, J. H. Hung, and K. F. Ma, 2007: Characteristics of the lithology, fault-related rocks and fault zone structures in TCDP Hole-A. Terr. Atmos. Ocean. Sci., 18, 243-269, doi: 10.3319/TAO.2007.18.2.243(TCDP).

Suppe, J., 1981: Mechanics of mountain building and metamorphism in Taiwan. Mem. Geol. Soc. China, 4, 67-89.

Taira, A., I. Hill, J. Firth, U. Berner, W. Bruckmann, T. Byrne, T. Chabernaud, A. Fisher, J. P. Foucher, T. Gamo, J. Gieskes, R. Hyndman, D. Karig, M. Kastner, Y. Kato, S. Lallemant, R. Lu, A. Maltman, G. Moore, K. Moran, G. Olaffson, W. Owens, K. Pickering, F. Sien, E. Taylor, M. Underwood, C. Wilkinson, M. Yamano, and J. Zhang, 1992: Sediment deformation and hydrogeology of the Nankai Trough accretionary prism: synthesis of shipboard results of ODP Leg 13. Earth Planet. Sci. Lett., 109, 413-450.

Tanaka, H., C. Y. Wang, W. M. Chen, A. Sakaguchi, K. Ujiie, H. Ito, and M. Ando, 2002: Initial science report of shallow drilling penetrating into the Chelungpu fault zone, Taiwan. Terr. Atmos. Ocean. Sci., 13, 227-251.

Teng, L. S., 1990: Geotectonic evolution of late Cenozoic arc-continent collision in Taiwan. Tectonophysics, 183, 57-76.

Wang, C. Y., C. H. Chang, and H. Y. Yen, 2000: An interpretation of the 1999 Chi-Chi earthquake in Taiwan based on the thin-skinned thrust model. Terr. Atmos. Ocean. Sci., 11, 609-630.

Wang, C. Y., C. L. Li, F. C. Su, M. T. Leu, M. S. Wu, S. H. Lai, and C. C. Chern, 2002: Structural mapping of the 1999 Chi-Chi earthquake fault, Taiwan by seismic reflection methods. Terr. Atmos. Ocean. Sci., 13, 211-226.

Wang, C. Y., C. L. Li, and H. C. Lee, 2004: Constructing subsurface structures of the Chelungpu fault to investigate mechanisms leading to abnormally large ruptures during the 1999 Chi-Chi earthquake, Taiwan. Geophys. Res. Lett., 31, L02608.

Wu, F. T., R. J. Rau, and D. Salzerg, 1997: Taiwan orogeny: thin-skinned or lithospheric collision? Tectonophysics, 247, 191-220. 
Yang, M., R. J. Rau, J. Y. Yu, and T. T. Yu, 2000: Geodetically observed surface displacements of the 1999 Chi-Chi, Taiwan, earthquake. Earth Planet. Space, 52, 403-413.

Yu, S. B., H. Y. Chen, and L. C. Kuo, 1997: Velocity field of GPS stations in the Taiwan area. Tectonophysics, 274, 41-59.

Yu, S. B., L. C. Kuo, Y. J. Hsu, H. H. Su, C. C. Lui, C. S. Hou, J. F. Lee, T. C. Lai, C. C. Liu, C. L. Liu, T. F. Tseng, C. S. Tsai, and T. C. Shin, 2001: Preseismic deformation and coseismic displacement associated with the 1999 Chi-Chi, Taiwan, earthquake. Bull. Seismol. Soc. Am., 91, 995-1012.

Yue, L. F., J. Suppe, and J. H. Hung, 2005: Structural geology of a classic thrust belt earthquake: The 1999 Chi-Chi earthquake Taiwan $\left(\mathrm{M}_{\mathrm{w}}=7.6\right)$. J. Struct. Geol., 27, 2058-2083.

Yeh, E. C., H. Sone, T. Nakaya, K. H. Ian, S. R. Song, J. H. Hung, W. Lin, T. Hirono, C. Y. Wang, K. F. Ma, W. Soh, and M. Kinoshita, 2007: Core description and characteristics of fault zones from Hole-A of the Taiwan Chelungpu-fault Drilling Project. Terr. Atmos. Ocean. Sci., 18, 327-357, doi: 10.3319/TAO.2007.18.2.327(TCDP). 